\title{
Chemical Quality of Waters of the Atoyac-Verde River As It Passes Through Forest Ecosystems of Oaxaca, Mexico
}

\author{
Edgar Iván Sánchez-Bernal ${ }^{\circledR} \cdot$ Héctor Manuel Ortega-Escobar ${ }^{\circledR} \cdot$ \\ Álvaro Can-Chulim • Verónica Ortega-Baranda $\odot$ \\ Marco Antonio Camacho-Escobar ${ }^{(D)}$ - Oscar Raúl Mancilla-Villa
}

Received: 30 September 2021 / Accepted: 21 January 2022 / Published online: 8 March 2022

(C) The Author(s) 2022

\begin{abstract}
In granitic regions, water salinity typically ranges from 30 to $40 \mathrm{mg} \mathrm{L}^{-1}$ at the surface and from 300 to $500 \mathrm{mg} \mathrm{L}^{-1}$ for groundwater. Technogenic activity in Oaxaca has altered the concentration and chemical composition, which explains the occurrence of salinization processes and contamination of natural waters. To determine the physical-chemical composition of the Atoyac-Verde river, fifty-two water samples were collected from tributaries and semi-deep wells in the basin. The $\mathrm{pH}$, electrical conductivity (EC), major cations and anions, total dissolved solids (TDS), residual sodium carbonate (RSC), and sodium adsorption ratio (SAR) were identified. Likewise,
\end{abstract}

Supplementary Information The online version contains supplementary material available at https://doi. org/10.1007/s11270-022-05515-x.

E. I. Sánchez-Bernal $(\bowtie) \cdot$ V. Ortega-Baranda Institute of Ecology, Universidad del Mar Campus Puerto Escondido, Km 1.5 Puerto Escondido-Oaxaca Road, vía Sola de Vega, C.P. 71989 Puerto Escondido, Oaxaca, Mexico

e-mail: edgarivansb@zicatela.umar.mx

H. M. Ortega-Escobar

Hydro - Science Program, Postgraduate College, Montecillo, México, Km 36.5 Mexico-Texcoco Road, C.P. 56230 Montecillo, State of Mexico, Mexico

Á. Can-Chulim

Academic Unit of Agriculture, Universidad

Autónoma de Nayarit, Km.9 Tepic -Compostela Road,

C.P. 63980 Xalisco, Nayarit, Mexico osmotic potential $(\Psi \pi)$ was evaluated, and the effective salinity (ES) and potential salinity (PS) indexes. Results indicate that the water of the basin is bicarbonate-magnesium-calcium. Of the 52 samples analyzed, only 2 identified in the high relief points presented high levels of alkalinity and salinity with a $\mathrm{pH}$ of $8.1, \mathrm{EC}$ of $2320 \mu \mathrm{S} \mathrm{cm}^{-1}, \Psi \pi$ of $-0.08 \mathrm{MPa}$, SAR of $3.74\left(\mathrm{mmol}_{\mathrm{c}} \mathrm{L}^{-1}\right)^{1 / 2}$, RSC of 0.53 , ES of 9.88, and PS of $7.79 \mathrm{mmol}_{\mathrm{c}} \mathrm{L}^{-1}$, indicating restriction for its use in agricultural and domestic activities. In the meso relief, the water did not present restrictive levels for anthropic use, while in the low relief, only two points presented high salinity levels and restriction of anthropic use. In conclusion, the greatest chemical alteration of the water was detected in areas close to the city of Oaxaca and to a lesser extent in areas

M. A. Camacho-Escobar

Institute of Industries, Universidad del Mar, Campus, Puerto Escondido,, Mexico

O. R. Mancilla-Villa

Agriculture Department, South Coast University Center, Universidad de Guadalajara, Independencia Nacional No. 151, C.P. 48900 Autlán de Navarro, Jalisco, Mexico 
adjacent to riverside populations of more than 2500 inhabitants.

Keywords Natural waters - Wastewater - Chemical contamination $\cdot$ Electrical conductivity $\cdot$ Salinity

\section{Introduction}

The ionic composition of the water of a basin derives from the weathering of the rocks which the water passes through a process that has occurred on the planet since the Archaean eon (Hazen, 2015). In nature, surface or underground waters are loaded with materials in solution such as mineral salts (nitrates, chlorides, sulfates, and carbonates), humic and fulvic substances, carbon dioxide, methane, elemental nitrogen, and/or materials in suspension such as clay and silt particles, as well as the residues of biological activity (Babayan, et al., 2021). Industrial development has damaged the various ecosystems due to misuse of water. This explains the shortage and temporary unavailability of water resources in the basins, as well as their contamination, factors that, given the growing demand for water, increase the costs and the risk of political and socio-economic conflict (Harari, 2016). In Mexico, the wide gap in socio-economic and cultural conditions between urban and rural populations creates inequality in the intensity of degradation of natural resources and in the availability and quality of the water used in productive activities (López et al., 2016; Sánchez et al., 2014). Deforestation, erosion, and climate change have put pressure on forest and water resources of the Atoyac-Verde river basin, producing slight changes in the chemical quality of the water in its downstream journey, attributed to the discharge of industrial and domestic wastewater from the city of Oaxaca, and the discharge of municipal waste water from riverside populations. Like other large hydrographic basins in Mexico, demand for water use in the exorheic areas of Oaxaca has led to the practice of reusing wastewater for irrigation. However, this practice produces negative impacts on the environment and human health which could be resolved through adequate water treatment (Lavrnré et al., 2017; Sánchez et al., 2012). In the AtoyacVerde River Basin (in the southern Pacific area of the state), forests and jungles in some protected areas grow and develop, while in others, deforestation influences the unavailability of water due to reduced uptake and its chemical quality due to an excessive load of sediments in the rainy season and the contribution of toxic substances which the soils cannot retain. It is conjectured that the chemical quality of the water presents qualitative variations not only due to the geology of the substrate, but also due to the discharge of wastewater from riverside populations and the degree of disturbance of the vegetation. The objective of this study was to determine the composition and chemical quality of the waters of the AtoyacVerde River.

\section{Materials and Methods}

\subsection{Area of Study}

The physical-chemical quality of the waters of the Atoyac-Verde River was analyzed, along its 437-km journey through the Costa Chica (R-20) hydrological region, located in the state of Oaxaca (INEGI, 2010). The main channel rises at $2270 \mathrm{~m} \mathrm{NW}$ of the city of Oaxaca in the town of Asunción Nochixtlán with coordinates (17 27 '26 "N; 97 $17^{\circ}$ ' 30" W), takes a winding path until it reaches the confluence with the "Verde" river that enters the Sierra Madre del Sur mountain chain, where it receives intermittent tributaries such as the Atoyaquillo, San Pedro, Río Grande, Campanario, and Sola de Vega before reaching its mouth in the Pacific Ocean in the town of Zapotalito, Municipality of San Pedro Tututepec, Oaxaca ( $16^{\circ} 02^{\prime} 6.7$ "N and $\left.97^{\circ} 25^{\prime} 32.45^{\prime \prime} \mathrm{W}\right)$. This basin comprises $3721.59 \mathrm{~km}^{2}$ representing $19.24 \%$ of the state territory and adjoins the basins of the Atoyac River (RH-18) and the Papaloapan River (RH-28) to the north; the Tehuantepec river basin $(\mathrm{RH}-22)$ to the east; La Arena river basin of the same region (RH-20) to the west; and the Colotepec river basin and others to the southeast (RH-21) and the Pacific Ocean to the south. The drainage network is dendritic with a general northwest-southeast orientation (INEGI, 2010). The basin receives an average of $2241.1 \mathrm{Mm}^{3}$ of rain per year, of which $504.25 \mathrm{Mm}^{3}$ runs off. In the high relief, the runoff is 0 to $5 \%$, which is due to an average rainfall of $700 \mathrm{~mm}$ per year and a shallow slope. Limestone rocks with high permeability dominate the meso relief where the runoff range is $5-10 \%$. In the steeper and less permeable areas of the Sierra, the 
runoff interval is $20-30 \%$, while in areas with 1500 $\mathrm{mm}$ rainfall, the runoff is $>30 \%$. The water is primarily used for agricultural and domestic activity. The Atoyac-Verde is one of the most polluted streams in the state, due to industrial waste water and municipal domestic waste from the most densely populated areas of the basin.

\subsection{Environmental Characterization}

The basin consists of a geology of metamorphic complexes. In the high relief, outcrops of metamorphic rocks of the Oaxaca complex can be found, such as paragneis, orthogneis, and anorthosites of Paleozoic age (Tolson, 2005). This metamorphic sequence presents intrusion of tertiary dioritic and graboic bodies. Underlying this complex in angular discordance are carbonate rocks of the Teposcolula formation characterized by the presence of Cretaceous limestones and dolomites, intruded by acidic granite rocks. (Mexican Geological Survey, 2005). In the meso and low relief areas of the basin, rocks from the Xolapa geological complex of Paleozoic age (De Scerna, 1965) made up of quartz-feldspathic gneiss. pelitic gneiss, amphibole gneiss, pegmatites, migmatites, and some marble horizons. The metamorphic rocks correspond to the Paleozoic age, and the granitic rocks to the Tertiary. Across this complex, there are some outcrops of underlying Cretaceous limestone rocks in angular unconformity; these deposits are located in the intermontane valleys, in the coastal alluvial plain, and in the banks of rivers and streams whose geomorphology is that of alluvial terraces (Mexican Geological Sirvey, 2005). The basin is affected by normal faults in the N-S and NW-SE direction intruded by granitic and metamorphic rocks of the Acatlán complex. The vegetation ranges from intermountain valleys and coniferous forests in the mountain ranges to tropical forests on the coasts and large areas with xerophytic vegetation. These changes in vegetation are associated with the variation of humid, sub-humid, and arid climates. The soils present a mosaic of lithosols, regosols, altosols, haplic pheozems, and cambisols with little development and some accumulation of calcium and clay. The vocation of land use is forestry, modified to give way to agriculture, livestock, and urban use. Therefore, forests and jungles are affected by deforestation and erosion which degrade vegetation and soils. In areas devoid of vegetation, the erosion advances in the surroundings of the city of Oaxaca, where the formation of gullies is observed.

\subsection{Water Sampling and Chemical Analysis}

From February 15 to 23,2018 , a prospective, analytical, cross-sectional, longitudinal, qualitative, and quantitative expedition was undertaken, to establish the water collection sampling points (Carrera et al., 2015). The collection was performed in low water through a random sampling of the waters of the Atoyac-Verde river from the high relief to the low relief of the basin, in order to determine its chemical quality. A total of 52 sampling points were selected that included waters of tributaries and the main river, in addition to springs and wells. A Garmin ${ }^{\circledR}$ MAP 70 brand geographic positioning system (GPS) was used to establish location. A water sample was collected at each monitoring point. Those from the river and springs were obtained from the central part of the tributary at a depth of $20 \mathrm{~cm}$, for which a 4-L capacity container was used. The liquid was then poured into 1-L polypropylene containers previously washed with distilled water (Richards, 1985). The water samples from the water wells were collected directly from the extraction systems, after washing the containers with the water itself. Accordingly, the depth of the water mirror of each well was measured with a tape measure. Water temperature, $\mathrm{pH}$, and electrical conductivity (EC) were determined on-site in $\mu \mathrm{S} \mathrm{cm}^{-1}$. The subsequent physical-chemical analyses were carried out in the soil and water area of the Wood Technology Laboratory of the Universidad del Mar and in the Salinity Laboratory of the Hydro-Sciences Program of the Postgraduate College in Montecillo, in Mexico State (Fig. 1).

The methods used in Table 1.

To distinguish differences in the chemical quality of the river water, the basin was divided into three regions based on altitude and isohyets in an upstream-downstream direction, identifying them as the following: (1) high relief; (2) meso relief; and (3) low relief. EC, $\mathrm{pH}$, major cations and anions, SAR, ES, and PS, DR, and CDR values were averaged. Results were subjected to a descriptive statistical analysis to ascertain the mean, standard deviation, and the coefficient of variation for the parameters $\mathrm{pH}$, EC, and CDR To determine significant differences between the water samples of each section, an 


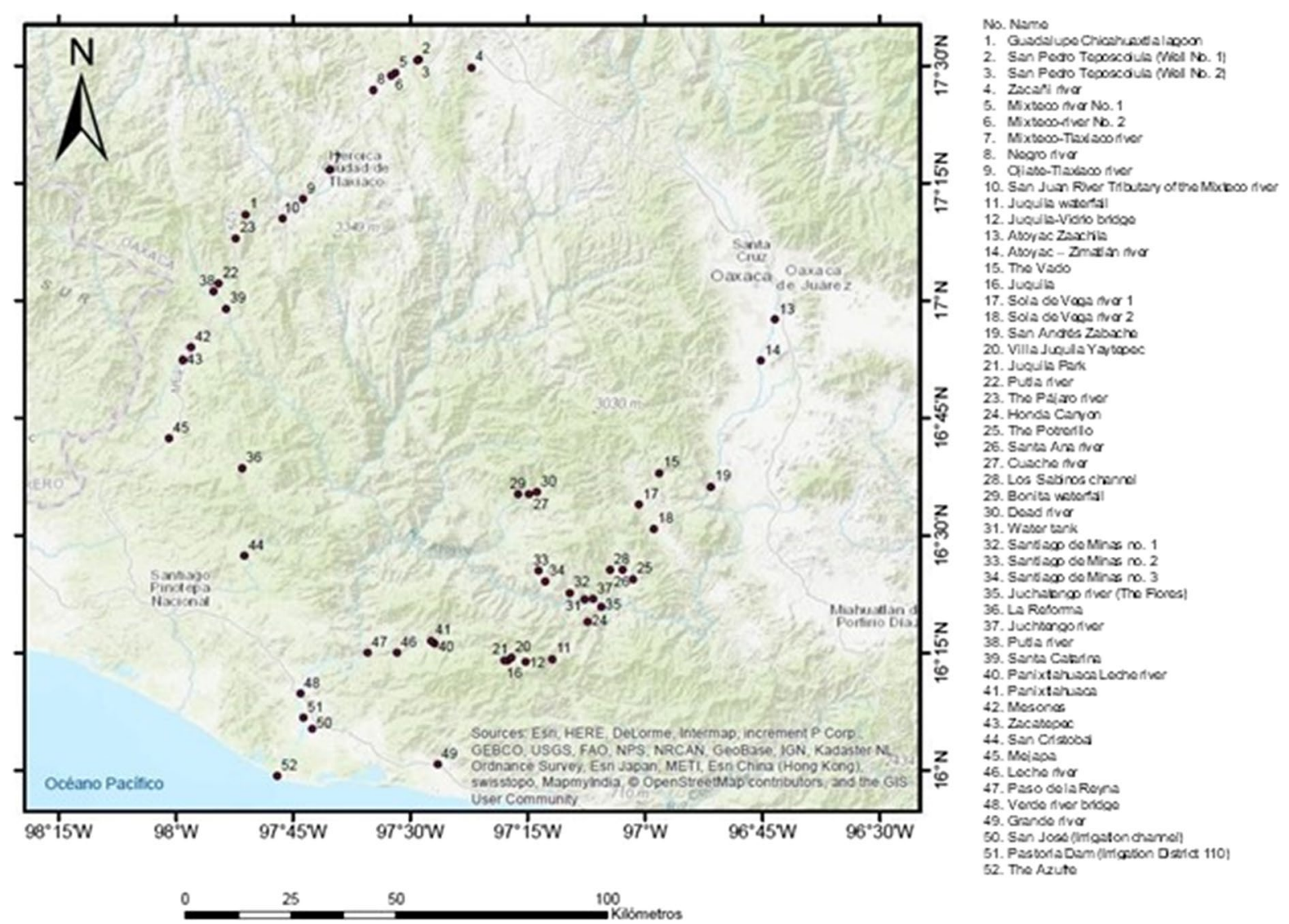

Fig. 1 Study area and sampling sites

analysis of variance was performed with the test of means and the Tukey $\alpha=0.05$ model, using the statistical analysis system (SAS, 2006). Graphs were made in Excel for the EC-SAR, ESP-SAR relationships, and the electro-neutrality of the water samples; in this case, the precision of the chemical analyses was estimated using its electro-neutral condition based on equality: Electroneutrality $(\%)=\frac{\sum_{i=1}^{n} \text { cations }-\sum_{i=1}^{n} \text { anions }}{\sum_{i=1}^{\text {ations }} \sum_{i=1} \text { anions }} \times 100$ where cations and anions are expressed in $\mathrm{mmol}_{\mathrm{c}} \mathrm{L}^{-1}$ and the sums indicate the cations $\mathrm{Ca}^{2+}, \mathrm{Mg}^{2+}, \mathrm{Na}^{+}$, and $\mathrm{K}^{+}$ and the anions $\mathrm{Cl}^{-}, \mathrm{HCO}_{3}{ }^{-}$, and $\mathrm{SO}_{4}^{-2}$.

\section{Results}

The high relief was made up of intervals of mean annual precipitation of 854 to $1573 \mathrm{~mm}$, as well as a height interval of 1200 to $2400 \mathrm{~m}$ above sea level (masl). The meso relief comprised an interval of pluvial precipitation from 551 to $1319 \mathrm{~mm}$ and an altitudinal interval from 600 to 1200 masl. In turn, the low relief was identified by a precipitation interval of 60 to $1254 \mathrm{~mm}$ and a height interval $<600$ masl. As for the description of vegetation, the work of Miranda and Hernández (1963) was taken into consideration. The high relief was made up of various communities of predominately holm and pine forests with the following species: Pinus sp., Abies Religiosa (Kunth) Schltdl. \& Cham., Arbutus sp., Morus sp., Quercus sp., Mulhenbergia sp., and Cochlearia sp. The biome is disturbed by agroecosystems of Coffea sp., Zea mays L. and Phaseolus vulgaris L., Musa sp., Mangífera indica L., Citrus sinensis (L.) Osbeck, Citrus limonum Risso, Psidium guajava L., Manilkara zapota (L.) P. Royen, Pouteria sapota (Jacq.) HE Moore \& Stearn, and Punica granatum L. and plots of various medicinal and aromatic herbs such as 
Table 1 Methods used in the physicochemical characterization of the Atoyac-Verde river

\begin{tabular}{|c|c|}
\hline Parameters & Methodology \\
\hline 1. $\mathrm{pH}$ & Multiparameter Hanna Instruments® model HI98129 Richards (1985) \\
\hline 2. $\mathrm{EC}\left(\mu \mathrm{S} \mathrm{cm}{ }^{-1}\right)$ & Multiparameter Hanna Instruments® model HI98129 Richards (1985) \\
\hline 3. DR (dry residue) in ppm & Water samples oven-dried at $105^{\circ} \mathrm{C}$ for $24 \mathrm{~h}$ (Richards, 1985) \\
\hline 4. CDR (calcined dry residue) in ppm & Water samples dried in muffle at $600^{\circ} \mathrm{C}$ for $24 \mathrm{~h}$ (Richards, 1985) \\
\hline $\begin{array}{l}\text { 5. Cations } \mathrm{Ca}^{2+} \text { and } \mathrm{Mg}^{2+} \\
\left(\mathrm{mmol}_{\mathrm{c}} \mathrm{L}^{-1}\right)\end{array}$ & Titration with EDTA (ethylene diamine-tetra-acetate) APHA method (1995) \\
\hline $\begin{array}{l}\text { 6. Cations } \mathrm{Na}^{+} \text {and } \mathrm{K}^{+} \\
\left(\mathrm{mmol}_{\mathrm{c}} \mathrm{L}^{-1}\right)\end{array}$ & Determination by brand® IL flamometer, model 653 (APHA, 1995) \\
\hline 7. Anions $\mathrm{CO}_{3}^{-2}$ and $\mathrm{HCO}_{3}^{-}\left(\mathrm{mmol}_{\mathrm{c}} \mathrm{L}^{-1}\right)$ & Titration with sulfuric acid $0.01 \mathrm{~N}$ \\
\hline 8. Anion $\mathrm{Cl}^{-}\left(\mathrm{mmol}_{\mathrm{c}} \mathrm{L}^{-1}\right)$ & Titration with silver nitrate $0.05 \mathrm{~N}$ \\
\hline 9. Anion $\mathrm{SO}_{4}^{-2}\left(\mathrm{mmol}_{\mathrm{c}} \mathrm{L}^{-1}\right)$ & Spectrophotometry Perking-Elmer spectrophotometer (APHA, 1995) \\
\hline 10. Osmotic potential (MPa) & $\begin{array}{l}\text { Osmometer }{ }^{\circledR} \text { Wescor } 5100 \mathrm{C} \text {, measurements corroborated with Richards } \\
\text { Eq. }(1985): \Psi_{\pi}=-0.036 \times \mathrm{EC}\end{array}$ \\
\hline 11. Sodium adsorption ratio (SAR) & SAR equation $=\frac{\sqrt{\mathrm{Na}^{+}}}{\sqrt{\frac{\mathrm{Ca}^{2+}+\mathrm{Mg}^{2+}}{2}}}\left(\mathrm{mmol}_{\mathrm{c}} \mathrm{L}^{-1}\right)^{1 / 2}($ Richards, 1985) \\
\hline 12. Exchangable sodium percentage (ESP) & ESP equation $=\frac{100(-0.0126+0.01475 x)}{1+(-0.0126+0.01475 x)}$, where: $x=$ SAR \\
\hline 13. Effective salinity (ES) & $\mathrm{ES}=\sum$ cations $-\mathrm{Ca}^{2+}+\mathrm{Mg}^{2+}\left(\mathrm{mmol}_{\mathrm{c}} \mathrm{L}^{-1}\right)(\mathrm{Can}$ et al., 2017) \\
\hline 14. Potential salinity (PS) & $\mathrm{PS}=\mathrm{Cl}^{-}+\frac{1}{2} \mathrm{SO}_{4}^{-2}\left(\mathrm{mmol}_{\mathrm{c}} \mathrm{L}^{-1}\right)($ Sánchez et al., 2019a, b) \\
\hline 15. Residual sodium carbonate (RSC) & $\mathrm{RSC}=\left(\mathrm{CO}_{3}^{-2}+\mathrm{HCO}_{3}^{-1}\right)-\left(\mathrm{Ca}^{2+}+\mathrm{Mg}^{2+}\left(\mathrm{mmol}_{\mathrm{c}} \mathrm{L}^{-1}\right)\right.$ \\
\hline
\end{tabular}

Mentha spicata L., Piper auritum Kunth, Ruta graveolen L., Dysphania ambrosioides (L.) Mosyakin \& Clemants, Ocimum bacilicum L., Arnica montana L., Malva sylvestris L., and Mentha pulegium L. The meso relief presents sub-deciduous biomes as well as pine and oak forest, of which CONAFOR (2015) has reported a deforestation of $30 \%$ due to the establishment of agroecosystems (Sánchez et al., 2014). The species that make up the lowland forest are the following: Protium copal (Schltdl. \& Cham.) Engl., Bursera simaruba (L.) Sarg., Enterolobium cyclocarpum (Jacq.) Griseb., Guazuma ulmifolia Lam., Lysiloma acapulcense (Kunth) Benth., Aracacea sp., Pithecellobium dulce (Roxb.) Benth.), and huizache (Vachellia farnesiana (L.) Wight and Arn.). In turn, the pine-oak forest, in addition to black oak, grows on very thin lithosols in which underlying low-permeability granitic rocks allow surface runoff and hydroerosive processes associated with deforestation to take place (Sánchez et al. 2019b). In the low relief, the vegetation is made up of low deciduous forest with species that shed their leaves in low water, such as Leucaena leucocephala (Lam.) De Wit, Lysiloma microphyllum Benth., Cordia dentata Poir., Acacia cornigera (L.) Willd., Cordia alliodora (Ruiz \&
Pav.) Cham., Lonchocarpus constrictus Pittier, Prosopis glandulosa Torr. Crataeva tapia L., Cochlospermum vitifolium (Willd.) Spreng., Guazuma ulmifolia Lam., and Gliricidia sepium Kunth ex Steud., whose description is in accordance with Ortega et al. (2018).

\subsection{Chemical Composition of the Waters of the Atoyac-Verde River Throughout the Basin}

Table 2 shows the chemical quality of the water of the main channel and tributaries of the high relief of the Atoyac-Verde River, which indicates an ionic composition dominated by $\mathrm{HCO}_{3}^{-}$ions and by $\mathrm{Ca}^{2+}$ and $\mathrm{Mg}^{2+}$ ions, with average concentrations of $3.37 \mathrm{mmol}_{\mathrm{c}}$ $\mathrm{L}^{-1}$ of $\mathrm{HCO}_{3}^{-}, 2.05 \mathrm{mmol}_{\mathrm{c}} \mathrm{L}^{-1}$ of $\mathrm{Mg}^{2+}$, and 1.30 $\mathrm{mmol}_{\mathrm{c}} \mathrm{L}^{-1}$ of $\mathrm{Ca}^{2+}$. The correlation $\mathrm{HCO}_{3}{ }^{-}-\mathrm{Ca}^{2+}$, $\mathrm{HCO}_{3}{ }^{-}-\mathrm{Mg}^{2+}$ are $r=0.67$ and that of $\mathrm{HCO}_{3}{ }^{-}-\mathrm{Na}^{+}$ is $r=0.87$, whereas the correlation $\mathrm{HCO}_{3}{ }^{-}-\mathrm{K}^{+}$is $r=0.73$, indicating a chemical association of these elements. The majority ions in these waters are the following order: $\mathrm{HCO}_{3}{ }^{-}>\mathrm{Cl}^{-1}>\mathrm{SO}_{4}{ }^{2-}$ and $\mathrm{Mg}^{2+}>\mathrm{Na}^{+}>\mathrm{Ca}^{2+}>\mathrm{K}^{+}$. Table 2 shows the $\mathrm{pH}$ values that vary from slightly acidic $(\sim 6.8)$ to water with alkaline reaction ( $\mathrm{pH} 7.10$ to 8.90 ). These $\mathrm{pH}$ values correspond to the sampling points "Guadalupe 
Table $2 \mathrm{pH}, \mathrm{EC}$, and ionic composition of waters of the high relief of Atoyac-Verde river basin

\begin{tabular}{|c|c|c|c|c|c|c|c|c|c|c|c|c|}
\hline \multirow[t]{3}{*}{ Sample number and identification } & \multirow[t]{3}{*}{$\mathrm{pH}$} & \multirow[t]{3}{*}{$\mathrm{EC}\left(\mu \mathrm{S} \mathrm{cm}^{-1}\right)$} & \multicolumn{5}{|c|}{ Cations } & \multicolumn{5}{|l|}{ Anions } \\
\hline & & & \multicolumn{10}{|c|}{$\left(\mathrm{mmol}_{\mathrm{c}} \mathrm{L}^{-1}\right)$} \\
\hline & & & $\mathrm{Ca}^{2+}$ & $\mathrm{Mg}^{2+}$ & $\mathrm{Na}^{+}$ & $\mathrm{K}^{+}$ & $\Sigma$ & $\mathrm{CO}_{3}{ }^{2-}$ & $\mathrm{HCO}_{3}{ }^{-}$ & $\mathrm{Cl}^{-}$ & $\mathrm{SO}_{4}^{2-}$ & $\Sigma$ \\
\hline 1. Guadalupe Chicahuaxtla lagoon & 8.9 & $140 \mathrm{c}$ & 0.32 & 0.46 & 0.50 & 0.09 & 1.37 & 0.04 & 0.85 & 0.40 & 0.04 & 1.33 \\
\hline 2. San Pedro Teposcolula (well no. 1) & 8.1 & $469 \mathrm{~b}$ & 0.63 & 1.63 & 2.27 & 0.06 & 4.59 & 0.00 & 2.53 & 1.60 & 0.31 & 4.44 \\
\hline 3. San Pedro Teposcolula (well no. 2) & 8.2 & $371 \mathrm{~b}$ & 0.85 & 1.22 & 1.44 & 0.12 & 3.63 & 0.11 & 2.09 & 1.13 & 0.30 & 3.63 \\
\hline 4. Zacañi river & 8.2 & $854 \mathrm{a}$ & 1.96 & 2.81 & 3.46 & 0.12 & 8.35 & 0.24 & 4.60 & 2.54 & 0.70 & 8.08 \\
\hline 5.. Mixteco river no. 1 & 8.0 & $894 \mathrm{a}$ & 2.10 & 2.95 & 3.48 & 0.13 & 8.66 & 0.00 & 4.95 & 2.69 & 0.77 & 8.41 \\
\hline 6. Mixteco river no. 2 & 8.1 & $611 \mathrm{~b}$ & 1.40 & 2.01 & 2.28 & 0.23 & 5.92 & 0.00 & 3.30 & 1.74 & 0.67 & 5.71 \\
\hline 7. Mixteco Tlaxiaco river & 8.2 & $637 \mathrm{~b}$ & 1.48 & 2.11 & 2.23 & 0.41 & 6.23 & 0.18 & 3.73 & 1.92 & 0.24 & 6.07 \\
\hline 8. Negro river & 8.3 & $1104 \mathrm{a}$ & 2.42 & 3.48 & 4.54 & 0.25 & 10.69 & 0.31 & 6.36 & 3.32 & 0.42 & 10.41 \\
\hline 9. Ojiate Tlaxiaco river & 7.7 & $733 \mathrm{~b}$ & 1.61 & 2.31 & 3.01 & 0.17 & 7.10 & 0.00 & 4.22 & 2.42 & 0.28 & 6.92 \\
\hline $\begin{array}{l}\text { 10.. San Juan River Tributary of the } \\
\text { Mixteco river }\end{array}$ & 8.5 & $338 \mathrm{~b}$ & 0.45 & 1.17 & 1.59 & 0.10 & 3.31 & 0.12 & 1.71 & 1.15 & 0.22 & 3.20 \\
\hline 11. Juquila waterfall & 6.8 & $73 \mathrm{c}$ & 0.15 & 0.22 & 0.30 & 0.05 & 0.72 & 0.00 & 0.43 & 0.22 & 0.05 & 0.70 \\
\hline 12. Juquila-Vidrio bridge & 6.8 & $52 \mathrm{c}$ & 0.07 & 0.18 & 0.20 & 0.06 & 0.51 & 0.00 & 0.27 & 0.17 & 0.06 & 0.50 \\
\hline 13. Atoyac Zaachila & 8.0 & $2350 a^{*}$ & 5.15 & 7.43 & 9.65 & 0.53 & 22.76 & 0.00 & 13.41 & 7.07 & 1.54 & $\mathrm{Z} 2.02$ \\
\hline 14. Atoyac-Zimatlán river & 8.1 & $2290 a^{*}$ & 5.25 & 7.56 & 9.26 & 0.32 & 22.39 & 0.00 & 13.05 & 6.81 & 1.86 & 21.72 \\
\hline 15. El Vado & 8.4 & $355 \mathrm{~b}$ & 1.18 & 1.58 & 0.56 & 0.12 & 3.44 & 0.12 & 1.88 & 1.07 & 0.28 & 3.35 \\
\hline 16. uquila & 7.6 & $297 \mathrm{~b}$ & 0.52 & 0.91 & 1.38 & 0.04 & 2.90 & 0.00 & 1.59 & 1.02 & 0.20 & 2.81 \\
\hline 17. Sola de Vega river 1 & 8.1 & $344 \mathrm{~b}$ & 0.48 & 1.20 & 1.56 & 0.12 & 3.36 & 0.00 & 1.82 & 1.20 & 0.24 & 3.26 \\
\hline 18. Sola de Vega river 2 & 7.9 & $442 \mathrm{~b}$ & 0.62 & 1.48 & 2.07 & 0.15 & 4.32 & 0.00 & 2.24 & 1.62 & 0.32 & 4.18 \\
\hline 19. San Andrés Zabache & 8.3 & $813 \mathrm{a}$ & 1.86 & 2.84 & 2.96 & 0.30 & 7.96 & 0.24 & 4.87 & 2.31 & 0.32 & 7.74 \\
\hline 20. Villa Juquila Yaytepec & 7.9 & $140 \mathrm{c}$ & 0.34 & 0.46 & 0.48 & 0.08 & 1.36 & 0.00 & 0.73 & 0.42 & 0.17 & 1.32 \\
\hline 21. Juquila Park & 8.3 & $164 \mathrm{c}$ & 0.36 & 0.54 & 0.58 & 0.11 & 1.59 & 0.16 & 0.79 & 0.52 & 0.08 & 1.55 \\
\hline 22. Putla river & 8.3 & $315 \mathrm{~b}$ & 0.72 & 1.12 & 1.02 & 0.22 & 3.08 & 0.10 & 1.46 & 0.94 & 0.48 & 2.98 \\
\hline 23. El Pájaro river & 8.7 & $390 \mathrm{~b}$ & 0.78 & 1.27 & 1.47 & 0.26 & 3.78 & 0.22 & 1.84 & 1.16 & 0.42 & 3.64 \\
\hline 24. Honda Canyon & 8.1 & $561 \mathrm{~b}$ & 1.12 & 1.83 & 2.16 & 0.32 & 5.43 & 0 & 3.31 & 1.68 & 0.26 & 5.25 \\
\hline 25. The Potrerillo & 8.3 & $465 \mathrm{~b}$ & 0.90 & 1.54 & 1.93 & 0.18 & 4.55 & 0.32 & 2.44 & 1.41 & 0.22 & 4.39 \\
\hline
\end{tabular}

$\mathrm{mmol}_{\mathrm{c}} \mathrm{L}^{-1}=$ millimole charge per liter. $\mathrm{a}, \mathrm{b}, \mathrm{c}=$ test of means for the variable. Different literals indicate statistical significance

${ }^{1}$ EC of water samples

${ }^{*}$ Significant difference (Tukey $\alpha=0.05$ )

Chicahuaxtla Lagoon," "San Pedro Teposcolula (well no. 1)," "San Pedro Teposcocolula (well no. 2)," "Zacañi river," "Mixteco river no. 1," "Ojiate Tlaxiaco river," "San Juan river (tributary of the Mixteco)," "Atoyac river," "El Vado," "Juquila river," "Sola de Vega river," "San Andrés Zabache," "Villa Juquila Yaytepec," "Putla river," "El Pájaro river," "Barranca Honda," and "El Potrerillo." An average $\mathrm{pH}$ of 8.10 was recorded at the points "Juquila waterfall" and the "Juquila-Vidrio bridge." Regarding the
EC, TDS, and $\Psi \pi$ of the water, the sampling points with the lowest EC were recorded at "Juquila waterfall" and the "Juquila-Vidrio bridge" with 52.10 and $72.80 \mu \mathrm{S} \mathrm{cm}^{-1}$, respectively. On the other hand, average EC values of $344.66 \mu \mathrm{S} \mathrm{cm} \mathrm{cm}^{-1}$ correspond to the sites "Guadalupe Chicahuaxtla Lagoon," "San Pedro Teposcolula (wells 1 and 2)," "Mixteco river no. 2," "San Juan river (tributary of Mixteco river)," "Mixteco Tlaxiaco river," "Juquila waterfall," "JuquilaVidrio bridge," "El Vado," "Juquila river," "Sola de 
Vega River no. 1," "Villa Juquila Yaytepec," "Juquila park," "Putla bridge," "El Pájaro river," "Barranca Honda," and "El Potrerillo." Higher ECs were recorded at the "Mixteco river no. 2" and "Mixteco Tlaxiaco river" sites with 637 and $611 \mu \mathrm{S} \mathrm{cm}-1$, respectively. Average EC levels of $879.80 \mu \mathrm{S} \mathrm{cm}-1$ were detected in the sites "Zacañi river," "Mixteco river no. 1," "Negro river," "Ojiate Tlaxiaco river," and "San Andrés Zabache"; in turn, ECs of 2320 $\mu \mathrm{S} \mathrm{cm}{ }^{-1}$ were detected in waters at the sites "Atoyac Zaachila" and "Atoyac Zimatlán river." The EC of these waters have high correlation with the total dissolved solids $(r=0.91)$. Table 2 identifies a high negative correlation between the values of EC and $\Psi \pi$ of the waters. The waters with low EC was - $0.01 \mathrm{MPa}$, while the waters with an intermediate EC of 879.60 $\mu \mathrm{S} \mathrm{cm}{ }^{-1}$ presented a $\Psi \pi$ of $-0.032 \mathrm{MPa}$ and in the sites with high EC, a mean $\Psi \pi$ of $-0.084 \mathrm{MPa}$. Table 3 shows that the values of ES and PS of the waters are variable, since 23 samples, representing $92 \%$ of the sampling of the high relief, registered an average of 1.48 mmol $_{\mathrm{c}} \mathrm{L}^{-1}$ of ES; 5 samples (Zacañi river, Mixteco river No. 1, Negro river, Ojiate river, and San Antonio Zabache) submitted a ES average of 3.60 mmolc $\mathrm{L}^{-1}$ and 2 samples "Atoyac Zaachila" and "Atoyac Zimatlán river" presented $9.08 \mathrm{mmol}_{\mathrm{c}} \mathrm{L}^{-1}$ of ES. On the other hand, almost all the samples of the high relief, had an average of $2.48 \mathrm{mmol}_{\mathrm{c}} \mathrm{L}^{-1} \mathrm{PS}$ Likewise, the samples "Atoyac Zaachila" and "Atoyac Zimatlan river" presented the highest $\left(7.79 \mathrm{mmol}_{\mathrm{c}}\right.$ $\mathrm{L}^{-1}$ of PS). These samples also presented the highest values of SAR $\left[8.60\left(\mathrm{mmol}_{\mathrm{c}} \mathrm{L}^{-1}\right)^{1 / 2}\right]$. The average SAR of the rest of the high relief samples was $<2.0$ $\left(\mathrm{mmol}_{\mathrm{c}} \mathrm{L}^{-1}\right)^{1 / 2}$. On the other hand, 18 samples $(72 \%)$ from upper area registered $\mathrm{Ca}^{2+}$ values of $1.78 \mathrm{ES}$ and 1.20 mmol $_{\mathrm{c}} \mathrm{L}^{-1} \mathrm{PS}$, while 5 samples (20\%) identified as "Zacañi river," "Mixteco river No, 1," "Negro river," "Ojiate Tlaxiaco river," and "San Andrés Zabache," presented averages of 3.68 ES and 2.90 PS in $\mathrm{mmol}_{\mathrm{c}} \mathrm{L}^{-1}$. Likewise, the sites "Atoyac Zaachila" and "Atoyac Zimatlán river" had the highest values of ES and PS with average of 9.8 and 7.7 mmol $_{c} \mathrm{~L}^{-1}$, respectively. These samples present a statistically difference contrasted with the rest $(P=0.05)$. According to their CSR (carbonate sodium residual) values, 23 samples, representing $92 \%$ of the waters of the Atoyac-Verde river in the high relief, were shown to have average values of $0.19\left(\mathrm{mmol}_{\mathrm{c}} \mathrm{L}^{-1}\right)$. Of all high relief water samples analyzed, only two (which represent 8\%), located in the sites "Negro river" and "Atoyac Zaachila river," yielded an average CSR of $0.80 \mathrm{mmol}_{\mathrm{c}} \mathrm{L}^{-1}$. Table 4 shows the ionic composition of the waters of the meso relief. The predominance of, $\mathrm{Mg}^{2+}, \mathrm{Ca}^{2+}$, and $\mathrm{HCO}_{3}{ }^{-}$ions is observed, whose average value is $0.63 \mathrm{mmol}_{\mathrm{c}} \mathrm{L}^{-1}, 0.60 \mathrm{mmol}_{\mathrm{c}} \mathrm{L}^{-1}$, and $2.01 \mathrm{mmol}_{\mathrm{c}} \mathrm{L}^{-1}$, respectively. The chemical association between $\mathrm{HCO}_{3}{ }^{-}-\mathrm{Ca}^{2+}$ and $\mathrm{HCO}_{3}{ }^{-}-\mathrm{Mg}^{2+}$ ions has a correlation of $r=0.94$; the correlation between $\mathrm{HCO}_{3}{ }^{-}$and $\mathrm{Na}^{+}$is $=0.97$ and that of the anion with $\mathrm{K}^{+}$yielded $r=0.72$. The major ions are presented in order of $\mathrm{HCO}_{3}{ }^{-}>\mathrm{SO}_{4}{ }^{-2}>\mathrm{Cl}^{-1}$ and $\mathrm{Mg}^{2+}$ $\mathrm{Ca}^{2+}>\mathrm{Na}^{+}>\mathrm{K}^{+}$. Table 4 presents the $\mathrm{pH}$ data of the waters of the meso relief which have values from 7.4 to 8.4 , that is, from slightly alkaline to alkaline. The minimum $\mathrm{pH}$ value corresponds to waters from the site "La Reforma" and the maximum corresponds to waters from the site "Putla river." The average $\mathrm{pH}$ of the 14 water samples collected in the meso relief is 8.04. The EC presented a minimum value of $30 \mu \mathrm{S}$ $\mathrm{cm}^{-1}$ for the site "Putla river" and a maximum value of $666 \mu \mathrm{S} \mathrm{cm}^{-1}$ for the site "Santa Ana river" with an average of $385.6 \mu \mathrm{S} \mathrm{cm} \mathrm{cm}^{-1}$. Table 5 identifies a high negative correlation of $r=-1$ between the EC and $\Psi \pi$ values. Basically, the average $\Psi \pi$ of the waters sampled in the meso relief was $-0.01 \mathrm{MPa}$, which is associated with low EC. The parameters ES, PS, SAR, and RSC indicate an ES $<3.0$, with an average of $1.71 \mathrm{mmol}_{\mathrm{c}} \mathrm{L}^{-1}$, and $\mathrm{PS}<3.0$, with an average of $1.26 \mathrm{mmol}_{\mathrm{c}} \mathrm{L}^{-1}$. Of the total samples, only five, identified as "Dead river," "Water tank," "Santiago de Minas No.1," "Santiago de Minas No. 3," and "Juchatengo river," registered an average SAR of 1.79 mmol $_{c} L^{-1 / 2}$. The remaining samples (9) had an average SAR of $\left(1.09 \mathrm{mmol}_{\mathrm{c}} \mathrm{L}^{-1}\right)^{1 / 2}$. On the other hand, the RSC values present an average of 0.14 mmol $_{c} \mathrm{~L}^{-1}$.

Table 6 presents the ionic composition of the waters in the low relief area of the basin, composed of 13 samples collected from the foothills of the coastal valley of Oaxaca to the outlet to the Pacific Ocean. The order of the major ions is as follows: $\mathrm{HCO}_{3}{ }^{-}>\mathrm{SO}_{4}{ }^{2-},>\mathrm{Cl}^{-1}$ and $\mathrm{Mg}^{2+}>\mathrm{Ca}^{2+}>\mathrm{Na}^{+}>\mathrm{K}^{+}$. $\mathrm{Mg}^{2+}, \mathrm{Ca}^{2+}$, and $\mathrm{HCO}_{3}{ }^{-}$ions predominate, which on average have $1.28 \mathrm{mmol}_{\mathrm{c}} \mathrm{L}^{-1}, 0.84 \mathrm{mmol}_{\mathrm{c}} \mathrm{L}^{-1}$, and $2.09 \mathrm{mmol}_{\mathrm{c}} \mathrm{L}^{-1}$, respectively. The $\mathrm{HCO}_{3}{ }^{-}-\mathrm{Mg}^{2+}$ correlation is $r=0.96$, while that of $\mathrm{HCO}_{3}{ }^{-}-\mathrm{Ca}^{2+}$ is $r=0.95$; the correlation $\mathrm{HCO}_{3}{ }^{-}-\mathrm{Na}^{+}$is $r=0.97$ and that of $\mathrm{HCO}_{3}{ }^{-} \mathrm{K}^{+}$is $r=0.73$. Table 6 indicates the $\mathrm{pH}$ of the waters of the study area; of the total samples, 
Table 3 Others physicochemical parameters of the Atoyac-Verde River in the high relief

\begin{tabular}{|c|c|c|c|c|c|c|c|c|}
\hline $\begin{array}{l}\text { Sample } \\
\text { number and } \\
\text { identification }\end{array}$ & $\begin{array}{l}\text { Altitude } \\
\text { (masl) }\end{array}$ & ${ }^{1} \Psi \pi(\mathrm{MPa})$ & $\begin{array}{l}{ }^{2} \mathrm{ES}\left(\mathrm{mmol}_{\mathrm{c}}\right. \\
\left.\mathrm{L}^{-1}\right)\end{array}$ & $\begin{array}{l}{ }^{3} \mathrm{PS}\left(\mathrm{mmol}_{\mathrm{c}}\right. \\
\left.\mathrm{L}^{-1}\right)\end{array}$ & $\begin{array}{l}{ }^{4} \mathrm{SAR} \\
\left(\mathrm{mmol}_{\mathrm{c}}\right. \\
\left.\mathrm{L}^{-1}\right)^{1 / 2}\end{array}$ & $\begin{array}{l}\text { ESP } \\
\%\end{array}$ & $\begin{array}{l}{ }^{5} \mathrm{RSC} \mathrm{mmol}_{\mathrm{c}} \\
\mathrm{L}^{-1}\end{array}$ & ${ }^{6} \mathrm{TDS}\left(\mathrm{mg} \mathrm{L}^{-1}\right)$ \\
\hline $\begin{array}{l}\text { 1. Guadalupe } \\
\text { Chicahuaxtla } \\
\text { Lagoon }\end{array}$ & 2439 & $-0.005 b$ & $0.59 \mathrm{c}$ & $0.42 \mathrm{c}$ & $0.80 \mathrm{~b}$ & 0.08 & $0.11 \mathrm{c}$ & $72 \mathrm{c}$ \\
\hline $\begin{array}{l}\text { 2. San Pedro } \\
\text { Teposcolula } \\
\text { (well no. 1) }\end{array}$ & 2276 & $-0.019 b$ & $2.33 \mathrm{~b}$ & $1.75 \mathrm{~b}$ & $2.13 \mathrm{~b}$ & 1.84 & $0.27 \mathrm{~b}$ & $76 \mathrm{c}$ \\
\hline $\begin{array}{l}\text { 3. San Pedro } \\
\text { Teposcolula } \\
\text { (well no. 2) }\end{array}$ & 2219 & $-0.014 b$ & $1.56 \mathrm{~b}$ & $1.28 \mathrm{~b}$ & $1.41 \mathrm{~b}$ & 0.81 & $0.13 \mathrm{c}$ & $212 b$ \\
\hline 4. Zacañi river & 2159 & $-0.033 b$ & $3.58 \mathrm{a}$ & $2.89 \mathrm{~b}$ & $2.24 \mathrm{~b}$ & 1.99 & $0.07 \mathrm{c}$ & $356 \mathrm{~b}$ \\
\hline $\begin{array}{l}\text { 5. Mixteco } \\
\text { river No. } 1\end{array}$ & 2130 & $-0.035 b$ & $3.61 \mathrm{a}$ & $3.07 \mathrm{a}$ & $2.19 \mathrm{~b}$ & 1.93 & $0.00 \mathrm{c}$ & $192 \mathrm{~b}$ \\
\hline $\begin{array}{l}\text { 6. Mixteco } \\
\text { river No. } 2\end{array}$ & 2125 & $-0.023 b$ & $2.51 \mathrm{~b}$ & $2.07 \mathrm{~b}$ & $1.74 \mathrm{~b}$ & 1.28 & $0.00 \mathrm{c}$ & $116 \mathrm{c}$ \\
\hline $\begin{array}{l}\text { 7. Mixteco } \\
\text { Tlaxiaco } \\
\text { river }\end{array}$ & 2075 & $-0.025 b$ & $2.64 \mathrm{~b}$ & $2.04 \mathrm{~b}$ & $1.66 \mathrm{~b}$ & 1.17 & $0.32 \mathrm{~b}$ & $208 \mathrm{~b}$ \\
\hline 8. Negro river & 2072 & $-0.044 b$ & $4.79 \mathrm{a}$ & $3.53 \mathrm{a}$ & $2.64 \mathrm{~b}$ & 2.56 & $0.77 \mathrm{a}$ & $624 \mathrm{a}$ \\
\hline $\begin{array}{l}\text { 9. Ojiate } \\
\text { Tlaxiaco } \\
\text { river }\end{array}$ & 1999 & $-0.029 b$ & $3.18 \mathrm{a}$ & $2.56 \mathrm{~b}$ & $2.15 \mathrm{~b}$ & 1.87 & $0.30 \mathrm{~b}$ & $312 \mathrm{a}$ \\
\hline $\begin{array}{l}\text { 10. San } \\
\text { Juan river } \\
\text { (Tributary of } \\
\text { the Mixteco } \\
\text { river) }\end{array}$ & 1958 & $-0.013 b$ & $1.69 \mathrm{~b}$ & $1.26 \mathrm{~b}$ & $1.76 \mathrm{~b}$ & 1.31 & $0.21 \mathrm{~b}$ & $144 \mathrm{~b}$ \\
\hline $\begin{array}{l}\text { 11. Juquila } \\
\text { waterfall }\end{array}$ & 1930 & $-0.003 c$ & $0.35 \mathrm{c}$ & $0.24 \mathrm{c}$ & $0.69 \mathrm{c}$ & -0.24 & $0.06 \mathrm{C}$ & $76 \mathrm{c}$ \\
\hline $\begin{array}{l}\text { 12. Juquila- } \\
\text { Vidrio } \\
\text { bridge }\end{array}$ & 1653 & $-0.002 c$ & $0.26 \mathrm{c}$ & $0.20 \mathrm{c}$ & $0.46 \mathrm{c}$ & -0.58 & $0.02 \mathrm{c}$ & $34 \mathrm{c}$ \\
\hline $\begin{array}{c}\text { 13. Atoyac } \\
\text { Zaachila }\end{array}$ & 1509 & $-0.093 a^{*}$ & $10.18 \mathrm{a}^{*}$ & $7.84 \mathrm{a}^{*}$ & $3.84 \mathrm{a}^{*}$ & 4.21 & $0.83 \mathrm{a}$ & $956 \mathrm{a}^{*}$ \\
\hline $\begin{array}{l}\text { 14. Atoyac- } \\
\text { Zimatlán } \\
\text { river }\end{array}$ & 1492 & $-0.091 a^{*}$ & $9.58 \mathrm{a}^{*}$ & $7.74 \mathrm{a}^{*}$ & $3.65 \mathrm{a}^{*}$ & 3.96 & $0.24 \mathrm{~b}$ & $957 a^{*}$ \\
\hline 15. El Vado & 1465 & $-0.012 b$ & $0.68 \mathrm{c}$ & $1.21 \mathrm{~b}$ & $0.47 \mathrm{c}$ & -0.56 & $0.00 \mathrm{c}$ & $124 \mathrm{~b}$ \\
\hline 16. Juquila & 1451 & $-0.012 b$ & $1.47 \mathrm{~b}$ & $1.12 \mathrm{~b}$ & $1.63 \mathrm{~b}$ & 1.13 & $0.16 \mathrm{c}$ & $120 \mathrm{~b}$ \\
\hline $\begin{array}{l}\text { 17. Sola de } \\
\text { Vega river } 1\end{array}$ & 1451 & $-0.014 b$ & $1.68 \mathrm{~b}$ & $1.32 \mathrm{~b}$ & $1.70 \mathrm{~b}$ & 0.98 & $0.14 \mathrm{c}$ & $208 \mathrm{~b}$ \\
\hline $\begin{array}{l}\text { 18. Sola de } \\
\text { Vega river } 2\end{array}$ & 1432 & $-0.018 b$ & $2.22 \mathrm{~b}$ & $1.78 \mathrm{~b}$ & $2.02 \mathrm{~b}$ & c1.69 & $0.14 \mathrm{c}$ & $244 \mathrm{~b}$ \\
\hline $\begin{array}{l}\text { 19. San } \\
\text { Andrés } \\
\text { Zabache }\end{array}$ & 1428 & $-0.032 b$ & $3.26 \mathrm{ac}$ & $2.47 \mathrm{~b}$ & $1.93 \mathrm{~b}$ & 1.56 & $0.41 \mathrm{a}$ & $312 b$ \\
\hline $\begin{array}{l}\text { 20. Villa } \\
\text { JuquilaYay- } \\
\text { tepec }\end{array}$ & 1418 & $-0.005 b$ & $0.56 \mathrm{c}$ & $0.50 \mathrm{c}$ & $0.75 \mathrm{c}$ & -0.15 & $0.00 \mathrm{c}$ & $60 \mathrm{c}$ \\
\hline $\begin{array}{l}\text { 21. Juquila } \\
\text { Park }\end{array}$ & 1404 & $-0.006 b$ & 0.69 & $0.56 \mathrm{c}$ & $0.86 \mathrm{c}$ & 0.00 & $0.05 \mathrm{c}$ & $88 \mathrm{c}$ \\
\hline
\end{tabular}


Table 3 (continued)

\begin{tabular}{|c|c|c|c|c|c|c|c|c|}
\hline $\begin{array}{l}\text { Sample } \\
\text { number and } \\
\text { identification }\end{array}$ & $\begin{array}{l}\text { Altitude } \\
\text { (masl) }\end{array}$ & ${ }^{1} \Psi \pi(\mathrm{MPa})$ & $\begin{array}{l}{ }^{2} \mathrm{ES}\left(\mathrm{mmol}_{\mathrm{c}}\right. \\
\left.\mathrm{L}^{-1}\right)\end{array}$ & $\begin{array}{l}{ }^{3} \mathrm{PS}\left(\mathrm{mmol}_{\mathrm{c}}\right. \\
\left.\mathrm{L}^{-1}\right)\end{array}$ & $\begin{array}{l}{ }^{4} \mathrm{SAR} \\
\left(\mathrm{mmol}_{\mathrm{c}}\right. \\
\left.\mathrm{L}^{-1}\right)^{1 / 2}\end{array}$ & $\begin{array}{l}\text { ESP } \\
\%\end{array}$ & $\begin{array}{l}{ }^{5} \mathrm{RSC} \mathrm{mmol}_{\mathrm{c}} \\
\mathrm{L}^{-1}\end{array}$ & ${ }^{6} \mathrm{TDS}\left(\mathrm{mg} \mathrm{L}^{-1}\right)$ \\
\hline 22. Putla river & 1386 & $-0.012 b$ & $1.24 \mathrm{a}$ & $1.18 \mathrm{~b}$ & $1.06 \mathrm{~b}$ & 0.30 & $00.00 \mathrm{c}$ & $176 \mathrm{~b}$ \\
\hline $\begin{array}{l}\text { 23. El Pájaro } \\
\text { river }\end{array}$ & 1380 & $-0.015 b$ & $1.73 \mathrm{a}$ & $1.37 \mathrm{~b}$ & $1.45 \mathrm{~b}$ & 0.87 & $0.01 \mathrm{c}$ & $176 \mathrm{~b}$ \\
\hline $\begin{array}{l}\text { 24. Honda } \\
\text { Canyon }\end{array}$ & 1238 & $-0.022 b$ & $2.48 \mathrm{a}$ & $1.81 \mathrm{~b}$ & $1.77 \mathrm{~b}$ & 1.33 & $0.36 \mathrm{~b}$ & $140 \mathrm{~b}$ \\
\hline $\begin{array}{l}25 \text {. The Potre- } \\
\text { rillo }\end{array}$ & 1214 & $-0.018 b$ & $2.11 \mathrm{a}$ & $1.52 \mathrm{~b}$ & $1.74 \mathrm{~b}$ & 1.28 & $0.32 \mathrm{~b}$ & $140 \mathrm{~b}$ \\
\hline
\end{tabular}

a, b, c $=$ test of means for the variables. ${ }^{1} \Psi \pi,{ }^{2} \mathrm{ES},{ }^{3} \mathrm{PS},{ }^{4} \mathrm{SAR},{ }^{5} \mathrm{CSR}$, and ${ }^{6} \mathrm{TDS}$ of water samples; different literals indicate statistical significance

*Significant difference (Tukey $\alpha=0.05$ )

Table $4 \mathrm{pH}$, EC, and ionic composition of the Atoyac-Verde river in the meso relief

\begin{tabular}{|c|c|c|c|c|c|c|c|c|c|c|c|c|}
\hline \multirow[t]{3}{*}{ Sample number and identification } & \multirow[t]{3}{*}{$\mathrm{pH}$} & \multirow[t]{3}{*}{${ }^{1} \mathrm{EC}\left(\mu \mathrm{S} \mathrm{cm}{ }^{-1}\right)$} & \multicolumn{5}{|c|}{ Cations } & \multicolumn{5}{|l|}{ Anions } \\
\hline & & & \multicolumn{10}{|c|}{$\left(\mathrm{mmol}_{\mathrm{c}} \mathrm{L}^{-1}\right)$} \\
\hline & & & $\mathrm{Ca}^{2+}$ & $\mathrm{Mg}^{2+}$ & $\mathrm{Na}^{+}$ & $\mathrm{K}^{+}$ & $\Sigma$ & $\mathrm{CO}_{3}{ }^{2-}$ & $\mathrm{HCO}_{3}^{-}$ & $\mathrm{Cl}^{-}$ & $\mathrm{SO}_{4}^{2-}$ & $\Sigma$ \\
\hline 26. Santa Ana river & 8.1 & $666 \mathrm{a}$ & 1.63 & 1.88 & 2.83 & 0.26 & 6.50 & 0.00 & 3.38 & 1.90 & 0.76 & 6.24 \\
\hline 27. Cuache river & 8.1 & $813 \mathrm{a}$ & 1.32 & 2.12 & 2.16 & 0.44 & 6.04 & 0.00 & 2.32 & 1.86 & 1.66 & 5.84 \\
\hline 28.Los sabinos channel & 8.2 & $375 \mathrm{~b}$ & 0.76 & 1.12 & 1,49 & 0.26 & 3.63 & 0.18 & 1.99 & 1.12 & 0.22 & 3.51 \\
\hline 29.Bonita waterfall & 8.3 & $138 \mathrm{c}$ & 0.28 & 0.38 & 0.58 & 0.11 & 1.35 & 0.12 & 0.74 & 0.38 & 0.08 & 1.32 \\
\hline 30. Dead river & 8.2 & $562 \mathrm{~b}$ & 1.09 & 1.76 & 2.37 & 0.22 & 5.44 & 0.28 & 3.09 & 1.65 & 0.26 & 5.28 \\
\hline 31.Water tank & 8.0 & $620 \mathrm{a}$ & 1.36 & 2.04 & 2.22 & 0.38 & 6.0 & 0.38 & 3.23 & 1.75 & 0.44 & 5.80 \\
\hline 32. Santiago de Minas no. 1 & 7.5 & $480 \mathrm{~b}$ & 1.02 & 1.52 & 1.93 & 0.18 & 4.65 & 0.00 & 2.92 & 1.38 & 0.18 & 4.48 \\
\hline 33. Santiago de Minas no. 2 & 8.0 & $195 \mathrm{~b}$ & 0.40 & 0.58 & 0.77 & 0.16 & 1.91 & 0.00 & 0.98 & 0.76 & 0.12 & 1.86 \\
\hline 34. Santiago de Minas no. 3 & 7.4 & $569 \mathrm{~b}$ & 1.18 & 1.82 & 2.28 & 0.28 & 5.56 & 0.00 & 3.28 & 1.82 & 0.28 & 5.38 \\
\hline 35.Juchatengo river (Las Flores) & 8.1 & $416 \mathrm{~b}$ & 0.82 & 1.32 & 1.77 & 0.16 & 4.07 & 0.00 & 2.43 & 1.33 & 0.20 & 3.96 \\
\hline 36. La reforma & 7.4 & $60 \mathrm{c}$ & 0.14 & 0.20 & 0.19 & 0.05 & 0.58 & 0,00 & 0.32 & 0.18 & 0.06 & 0.56 \\
\hline 37.Juchtengo river & 8.2 & $393 \mathrm{~b}$ & 0.88 & 1.28 & 1.48 & 0.20 & 3.84 & 0.16 & 2.05 & 1.34 & 0.20 & 3.75 \\
\hline 38. Putla river & 8.4 & $30 \mathrm{c}$ & 0.07 & 0.12 & 0.07 & 0.03 & 0.29 & 0.03 & 0.15 & 0.07 & 0.03 & 0.28 \\
\hline 39. Santa Catarina & 8.2 & $275 \mathrm{~b}$ & 0.60 & 0.84 & 1.11 & 0.14 & 2.69 & 0.14 & 1.36 & 0.94 & 0.16 & 2.60 \\
\hline
\end{tabular}

$\mathrm{mmol}_{\mathrm{c}} \mathrm{L}^{-1}=$ millimole charge per liter. a, b, $\mathrm{c}=$ Test of means for the variable. Different letters indicate statistical significance

${ }^{1} \mathrm{EC}$ of water samples

*Significant difference (Tukey $\alpha=0.05$ )

six ("Panixtlahuaca-Leche river," "San Cristóbal," "Mejapa," "Leche river," "Grande river," and "Pastoría Dam Irrigation District 110), that is, $46.15 \%$ of the total have an average of 7.6 and are alkaline. Seven samples $(53.84 \%$ of the total), registering an average $\mathrm{pH}$ of 8.1 , were identified as having high alkalinity, and correspond to the sites "Panixtlahuaca," "Mesones," "Zacatepec river," "Paso de la Reyna," "Verde river bridge," "San José del Progreso (irrigation channel)," and "El Azufre." Regarding EC values, 11 samples $(84.6 \%)$ presented an average of $255.85 \mu \mathrm{S} \mathrm{cm}^{-1}$, while the two remaining samples that correspond to the sites "El Azufre" and "San Cristóbal" registered the highest $\mathrm{EC}$ of $1199.50 \mu \mathrm{S} \mathrm{cm} \mathrm{cm}^{-1}$. As in the high and meso relief areas, the waters of the low relief show a high correlation between EC and TDS values. 
Table 5 Others physicochemical parameters of tributary waters of the Atoyac Verde River in the meso relief

\begin{tabular}{|c|c|c|c|c|c|c|c|c|}
\hline $\begin{array}{l}\text { Sample } \\
\text { number and } \\
\text { identification }\end{array}$ & $\begin{array}{l}\text { Altitude } \\
\text { (masl) }\end{array}$ & $\begin{array}{l}{ }^{1} \text { Osmotic } \\
\text { Potential } \\
(\Psi \pi)\end{array}$ & $\begin{array}{l}{ }^{2} \mathrm{ES}\left(\mathrm{mmol}_{\mathrm{c}}\right. \\
\left.\mathrm{L}^{-1}\right)\end{array}$ & $\begin{array}{l}{ }^{3} \mathrm{PS}\left(\mathrm{mmol}_{\mathrm{c}}\right. \\
\left.\mathrm{L}^{-1}\right)\end{array}$ & $\begin{array}{l}{ }^{4} \mathrm{SAR} \\
\left(\mathrm{mmol}_{\mathrm{c}}\right. \\
\left.\mathrm{L}^{-1}\right)^{1 / 2}\end{array}$ & ESP $\%$ & $\begin{array}{l}{ }^{5} \mathrm{RSC}\left(\mathrm{mmol}_{\mathrm{c}}\right. \\
\left.\mathrm{L}^{-1}\right)\end{array}$ & ${ }^{6} \mathrm{TDS}\left(\mathrm{mg} \mathrm{L}^{-1}\right)$ \\
\hline $\begin{array}{l}\text { 1. Santa Ana } \\
\text { river }\end{array}$ & 1160 & $-0.026 b$ & $2.99 \mathrm{a}$ & $2.28 \mathrm{a}$ & $1.30 \mathrm{~b}$ & 0.65 & $-0.13 b$ & $300 \mathrm{a}$ \\
\hline $\begin{array}{l}\text { 2. Cuache } \\
\text { river }\end{array}$ & 1116 & $-0.023 b$ & $2.60 \mathrm{a}$ & $2.69 \mathrm{a}$ & $1.63 \mathrm{~b}$ & 1.42 & $-1.12 b$ & $396 \mathrm{a}$ \\
\hline $\begin{array}{l}\text { 3. Los Sabinos } \\
\text { channel }\end{array}$ & 1108 & $-0.014 \mathrm{a}$ & $1.75 \mathrm{~b}$ & $1.13 \mathrm{~b}$ & $1.53 \mathrm{~b}$ & 0.98 & $0.29 \mathrm{a}$ & $212 \mathrm{a}$ \\
\hline $\begin{array}{l}\text { 4. Bonita } \\
\text { Waterfall }\end{array}$ & 1085 & $-0.005 \mathrm{a}$ & $0.69 \mathrm{~b}$ & $0.42 \mathrm{c}$ & $1.01 \mathrm{~b}$ & 0.22 & $-0.32 b$ & $64 \mathrm{c}$ \\
\hline 5. Dead river & 1049 & $-0.022 b$ & $2.59 \mathrm{a}$ & $1.78 \mathrm{~b}$ & $1.98 \mathrm{a}$ & 1.63 & $0.52 \mathrm{a}$ & $328 \mathrm{a}$ \\
\hline 6. Water tank & 1013 & $-0.029 b$ & $2.60 \mathrm{a}$ & $0.97 \mathrm{~b}$ & $1.70 \mathrm{a}$ & 1.23 & $0.21 \mathrm{a}$ & $200 \mathrm{a}$ \\
\hline $\begin{array}{l}\text { 7. Santiago de } \\
\text { Minas no. } 1\end{array}$ & 1004 & $-0.019 b$ & $2.11 \mathrm{a}$ & $1.47 \mathrm{~b}$ & $1.71 \mathrm{~b}$ & 1.24 & $0.38 \mathrm{a}$ & $112 \mathrm{~b}$ \\
\hline $\begin{array}{l}\text { 8. Santiago de } \\
\text { Minas no. } 2\end{array}$ & 963 & $-0.007 \mathrm{a}$ & $0.93 \mathrm{~b}$ & $0.82 \mathrm{c}$ & $1.10 \mathrm{~b}$ & 0.36 & $0.00 \mathrm{~b}$ & $100 \mathrm{~b}$ \\
\hline $\begin{array}{l}\text { 9. Santiago de } \\
\text { Minas no. } 3\end{array}$ & 928 & $-0.023 b$ & $2.56 \mathrm{a}$ & $1.96 \mathrm{a}$ & $1.86 \mathrm{a}$ & 1.46 & $0.28 \mathrm{a}$ & $120 \mathrm{~b}$ \\
\hline $\begin{array}{l}\text { 10. Juchatengo } \\
\text { river (Las } \\
\text { Flores) }\end{array}$ & 847 & $-0.017 \mathrm{a}$ & $1.93 \mathrm{~b}$ & $1.43 \mathrm{~b}$ & $1.71 \mathrm{~b}$ & 1.24 & $0.29 \mathrm{a}$ & $172 \mathrm{~b}$ \\
\hline $\begin{array}{l}\text { 11. La } \\
\text { Reforma }\end{array}$ & 842 & $-0.002 \mathrm{a}$ & $0.24 \mathrm{c}$ & $0.21 \mathrm{c}$ & $0.46 \mathrm{c}$ & 0.58 & $-0.02 b$ & $44 \mathrm{c}$ \\
\hline $\begin{array}{l}\text { 12. Juchatengo } \\
\text { river }\end{array}$ & 830 & $-0.015 \mathrm{a}$ & $1.68 \mathrm{~b}$ & $1.44 \mathrm{~b}$ & $1.42 \mathrm{~b}$ & -1.18 & $-0.11 b$ & $249 \mathrm{a}$ \\
\hline 13. Putla river & 741 & $-0.001^{\mathrm{a}}$ & $0.10 \mathrm{c}$ & $0.08 \mathrm{c}$ & $0.22 \mathrm{c}$ & -1.27 & $-0.01 \mathrm{~b}$ & $172 \mathrm{~b}$ \\
\hline $\begin{array}{l}\text { 14. Santa } \\
\text { Catarina }\end{array}$ & 736 & $-0.010 \mathrm{a}$ & $1.25 \mathrm{~b}$ & $1.02 \mathrm{~b}$ & $1.30 \mathrm{~b}$ & 0.66 & $0.06 \mathrm{~b}$ & $148 \mathrm{~b}$ \\
\hline
\end{tabular}

a, b, c $=$ test of means for variables. ${ }^{1} \Psi \pi,{ }^{2} \mathrm{ES},{ }^{3} \mathrm{PS},{ }^{4} \mathrm{SAR},{ }^{5} \mathrm{RSC}$, and ${ }^{6} \mathrm{TDS}$ of water samples, Different literals indicate statistical significance

${ }^{*}$ Significant difference (Tukey $\alpha=0.05$ )

The water samples that showed a low average TDS were the sites "Panixtlahuaca-Leche river," "Panixtlahuaca," "Mesones," "Zacatepec," "Mejapa," "Leche river," "Paso de la Reyna," "Verde river bridge," "Grande river," "San José (irrigation channel)," and "Pastoría Dam Irrigation District 110," with an average of $122.54 \mathrm{mg} \mathrm{L}^{-1}$. At "El Azufre" and "San Cristóbal," the TDS presented an average of $698 \mathrm{mg} \mathrm{L}^{-1}$. Regarding $\Psi \pi, 11$ samples from the low relief presented an average of $-0.01 \mathrm{MPa}$, in contrast to the waters of "El Azufre" and "San Cristóbal," decreased the $\Psi \pi$ to an average of $-0.08 \mathrm{MPa}$. The correlation $\mathrm{EC}-\Psi \pi$ is negative and yielded a value of $r=-1$. On the other hand, $84.61 \%$ of the samples in the low relief presented an average ES of $1.08 \mathrm{mmol}_{\mathrm{c}} \mathrm{L}^{-1}$ and average PS of $0.92 \mathrm{mmol}_{\mathrm{c}} \mathrm{L}^{-1}$. In addition, only 2 samples of the lower zone (15.38\%) known as "San Cristobal" and "El Azufre" had an average ES of 5.26 mmol $_{c} \mathrm{~L}^{-1}$ and PS of $3.83 \mathrm{mmol}_{\mathrm{c}} \mathrm{L}^{-1}$. Regarding the SAR values, these samples presented an average of 2.76 mmolc $\mathrm{L}^{-1}$; the rest of the samples did not have values greater than $3 \mathrm{mmol}_{\mathrm{c}} \mathrm{L}^{-1}$. The average RSC for all samples had a value of $0.18 \mathrm{mmol}_{\mathrm{c}} \mathrm{L}^{-1}$.

\section{Discussion}

Results of Tables 2, 4, and 6 show the predominance of the anion $\mathrm{HCO}_{3}{ }^{-}$over $\mathrm{Cl}^{-1}$ and $\mathrm{SO}_{4}{ }^{2-}$, as well as the cations $\mathrm{Mg}^{2+}$ and $\mathrm{Ca}^{2+}$ over $\mathrm{Na}^{+}$and $\mathrm{K}^{+}$. This composition is due to the passage of the waters of the Atoyac River through ferromagnesic rocks of 


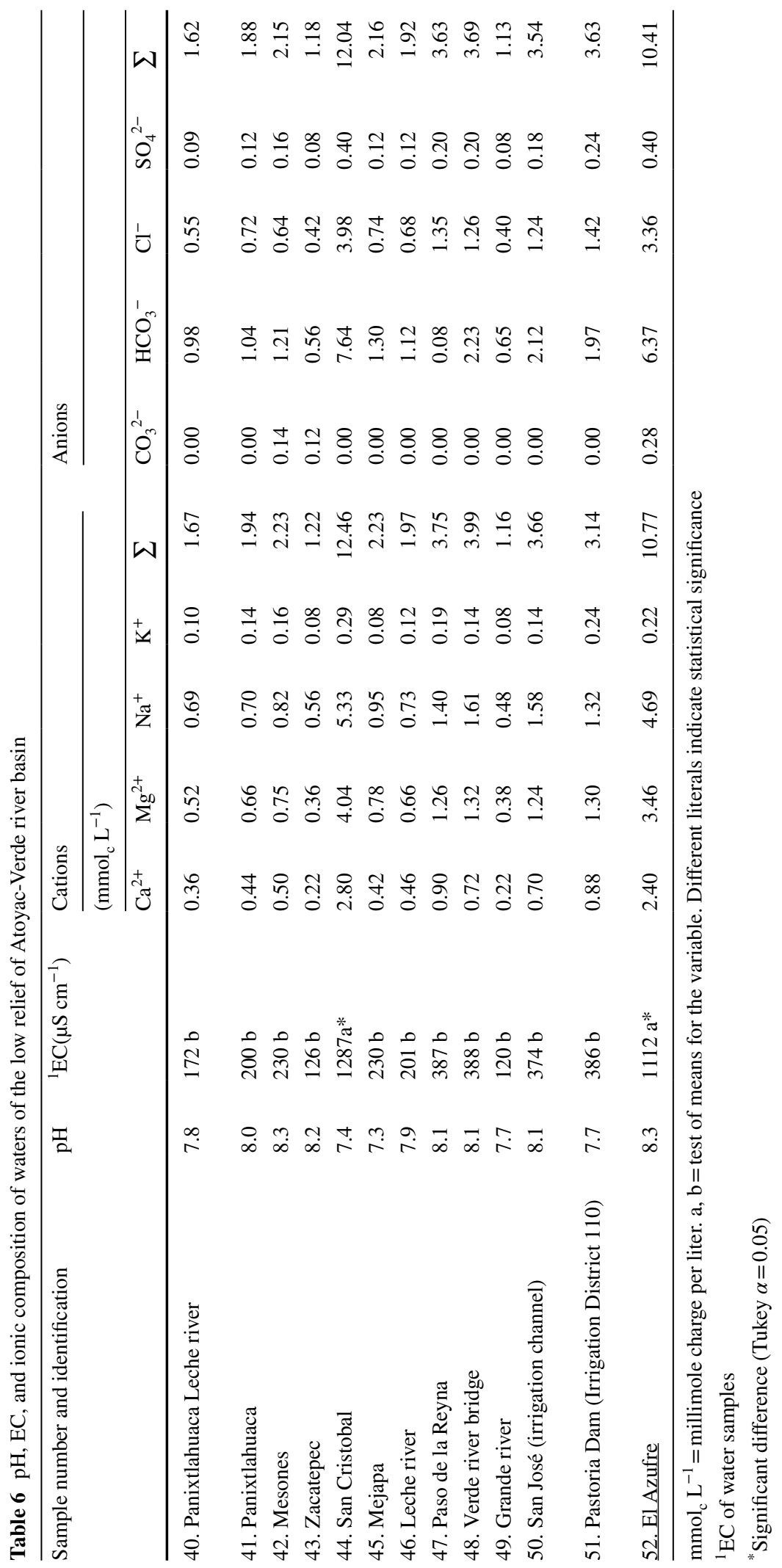


the Oaxaca geological formation in the high relief, as well as through granitic and metamorphic rocks of calcic-magnesium composition of the Xolapa geological formation of Paleozoic age in the meso and low relief (De Scerna, 1965). According to the Piper Diagram (Ray \& Mukherjee, 2008), the waters of the upper, meso, and low relief are classified as magnesium-calcium-bicarbonate (Fig. 2a, b, c). A detailed analysis of the majority ions in these waters indicates that $\mathrm{Ca}^{2+}$ and $\mathrm{Mg}^{2+}$ predominate in their constitution because, according to Hazen (2015), they are the most abundant elements in natural waters due to their interaction with the type of rock which they pass through. These waters mainly present $\mathrm{HCO}_{3}{ }^{-}$ions and to a lesser degree $\mathrm{SO}_{4}{ }^{2-}$ and $\mathrm{Cl}^{-1} \cdot \mathrm{Ca}^{2+}$ and $\mathrm{Mg}^{2+}$ are a binomial that gives water hardness (Szabolcs, 1994). In the case of $\mathrm{Mg}^{2+}$, its concentration is lightly higher than that of $\mathrm{Ca}^{2+}$, which is due to the high solubility of the magnesium salts that remain in solution and precipitate less than the $\mathrm{Ca}^{2+}$ ion that tend to precipitate in the form of poorly soluble mineral salts (Mercado et al., 2021). The turquoise green color of the
Atoyac-Verde river is due to the presence of $\mathrm{Mg}^{2+}$. The concentration of these ions in the Atoyac-Verde is higher than that detected in the Copalita river, due to the fact that the present study was carried out in dry season and the one corresponding to the Copalita river was performed in the rainy season (Sánchez et al., 2014). Taken together, all of the evidence seems to indicate that the concentration of these divalent cations should be lower in the Atoyac river in the rainy season. The concentration of $\mathrm{Ca}^{2+}$ and $\mathrm{Mg}^{2+}$ of the waters of the Atoyac-Verde river and its tributaries throughout the basin does not exceed the permissible limits for ionic concentration of water for human consumption indicated by the Water Quality Standard NOM-127-SSA-2000 of the Ministry of Health, nor the limits established by the water quality guidelines of the World Health Organization (2006). Regarding the $\mathrm{Na}^{+}$ion, six samples from the high relief presented this element in trace amounts $\left(<1 \mathrm{mmol}_{\mathrm{c}}\right.$ $\mathrm{L}^{-1}$ ): this is due to the fact that $\mathrm{Na}^{+}$is an element of excessive mobility in solution and of rapid migration. According to Kovda (1977), because its ionic radius
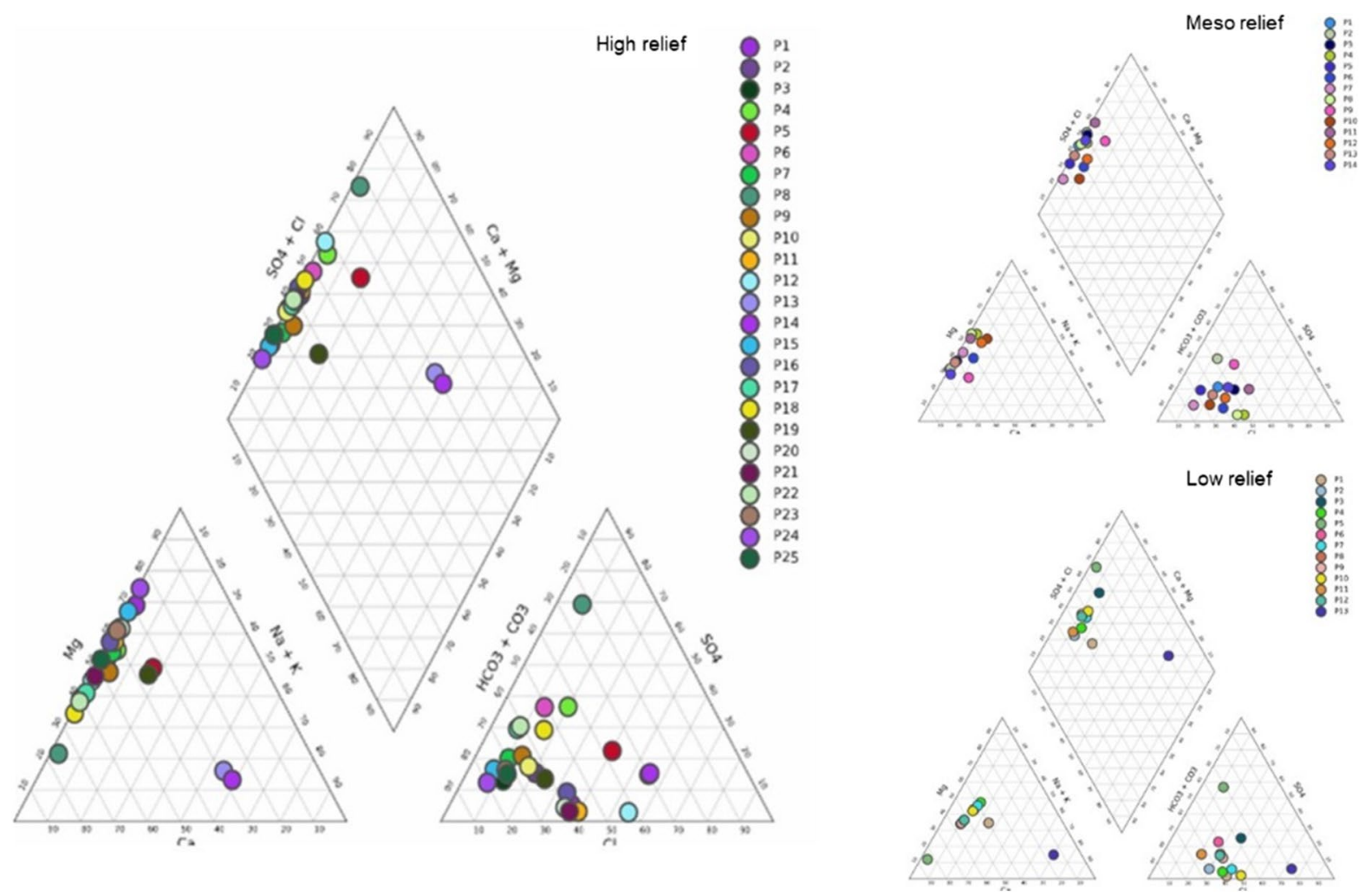

Fig. 2 Piper diagram. a Waters of the high relief area, $\mathbf{b}$ waters of the meso relief area, and $\mathbf{c}$ waters of the low relief area 
$\left(0.95 \mathrm{~A}^{\circ}\right)$, hydration radius $\left(1.54 \mathrm{~A}^{\circ}\right)$, hydration number (16.2 mol of water), and ionic selectivity coefficient (0.45) favor its mobility (Sánchez et al. 2019b), during mineral weathering, the juvenile waters of the high relief are not heavily charged with this ion which is quickly lost in water drainage. However, in nineteen water samples from high relief, the average $\mathrm{Na}^{+}$ concentration was of $3.04 \mathrm{mmol}_{\mathrm{c}} \mathrm{L}^{-1}$.

This change in concentration is largely due to two processes: (1) the solubilization and reconcentration of mineral salts loaded with sodium due to weathering processes and (2) the discharge of municipal wastewater from riverside populations which is released into the river, increasing the sodicity of the waters. A similar process occurs in sites with populations $>2500$ inhabitants in the Copalita Basin (Sánchez et al., 2014). It should be noted that only in two high relief sites such as "Atoyac-Zaachila" and "Atoyac-Zimatlán river" elevated $\mathrm{Na}^{+}$concentrations of the order of $9.45 \mathrm{mmol}_{\mathrm{c}} \mathrm{L}^{-1}$ were detected. This jump in concentration is explained by the discharge of industrial urban wastewater and runoff from diffuse sources that the river receives as it passes through the city of Oaxaca. These samples do exceed the permissible limits for $\mathrm{Na}^{+}$, established by the water quality standards already indicated. Therefore, the wastewater of the city of Oaxaca should be considered a source of contamination of the Atoyac-Verde river. In the meso relief, only four samples out of the fourteen total presented an average $\mathrm{Na}^{+}$concentration of $0.40 \mathrm{mmol}_{\mathrm{c}} \mathrm{L}^{-1}$; with the rest, the presence of this element was detected with an average of $1.96 \mathrm{mmol}_{\mathrm{c}}$ $\mathrm{L}^{-1}$, which indicates that, in this area, the waters of the river receive the contribution of $\mathrm{Na}^{+}$derived from weathering processes. In addition, these waters do not exceed the permissible limits for $\mathrm{Na}^{+}$established by the water quality standards NOM-127-SSA1-2000 and by the World Health Organization water quality guidelines (2006). According to Sánchez et al., (2019a, b), the waters are suitable only for irrigation and animal consumption. On the other hand, in the coastal plain, only two samples of a total of thirteen had a $\mathrm{Na}^{+}$content of $5.01 \mathrm{mmol}_{\mathrm{c}} \mathrm{L}^{-1}$. This concentration is due to the contribution of $\mathrm{NaCl}$ salts from the Pacific Ocean in the form of marine intrusions (Barlow \& Reichard, 2010) and the contribution of groundwater to the coastline (Mancilla et al., 2020; Mercado et al., 2021); this natural phenomenon occurs at the site "El Azufre." Likewise, eleven water samples from the coastal plain show an average $\mathrm{Na}^{+}$ value of $0.98 \mathrm{mmol}_{\mathrm{c}} \mathrm{L}^{-1}$. Based on national and international water quality standards, the water sources in question are suitable for human consumption and for use in agriculture irrigation.

Only "El Azufre" and "San Cristobal" water samples, due to its high sodium concentration, are unsuitable for human consumption or agricultural use, since it exceeds the permissible limits established by the aforementioned standards. In the case of the $\mathrm{K}^{+}$ion, the element was found in trace amounts $<1 \mathrm{mmol}_{\mathrm{c}}$ $\mathrm{L}^{-1}$ in the high, meso, and low relief waters, which coincides with that indicated by Zuñiga et al. (2010), who argue that $\mathrm{K}^{+}$generally constitutes a small fraction of the cations in water due to its geochemical mobility. The great resistance of potassium feldspars and potassium silicates to weathering must also be considered, which is why this element recharges river waters in minimal quantities. In addition, due to its rapid migration, this ion accumulates in the meso and low relief soils of a basin, where it is fixed by clays and other secondary minerals in the soils (Mercado et al., 2021). The waters of the Atoyac-Verde river present average concentrations of the $\mathrm{HCO}_{3}{ }^{-}$ion in their chemical composition: 3.37, 2.01, and 2.09 mmol $_{c} \mathrm{~L}^{-1}$ for the high, meso, and low relief areas of the basin, respectively. The greater presence of this anion compared to others is explained by the fact that it derives from carbon dioxide $\left(\mathrm{CO}_{2}\right)$ produced not only by the decomposition of organic matter in the soil, but also by the respiration of plant roots, the reduction of $\mathrm{SO}_{4}{ }^{2-}$, and the passage of the waters through dolomitic and calcic rocks (Palacios and Gama, 1994). The concentrations of $\mathrm{HCO}_{3}{ }^{-}$in the Atoyac-Verde river are presumably caused by oxidation processes in the alluvial areas through which the river flows. In any case, these concentrations induce alkalinity in these waters (Mancilla et al., 2020). The concentrations indicated do not exceed the permissible limits of water for human consumption established by the Chemical Mexican Standard NOM 127SSA-1 (2000), nor by the World Health Organization (2006). Regarding the $\mathrm{Cl}^{-}$ion, its low concentrations of $1.66,1.17$, and $1.28 \mathrm{mmol}_{\mathrm{c}} \mathrm{L}^{-1}$ in the upper, meso, and low relief areas indicate that the river does not have restrictive levels of this ion and when it does occur, it tends to form salts of $\mathrm{NaCl}, \mathrm{MgCl}_{2}, \mathrm{KCl}$, and $\mathrm{CaCl}_{2}$, which, due to their low concentration, do not generate salinity problems and in fact serve as plant 
nutrition (Szabolcs, 1994). With respect to this, 49 water samples comprising $96.9 \%$ of the total collected in the basin, revealed concentrations which do not exceed the permissible limits established by the indicated water quality standards. In contrast, the high relief water samples "Negro river," "AtoyacZaachila," and "Atoyac-Zimatlán river" show concentrations of $\mathrm{Cl}^{-}$slightly $>1.0 \mathrm{mmol}_{\mathrm{c}} \mathrm{L}^{-1}$, and do not exceed the permissible water quality limits, and the same was true for the low relief water samples "San Cristobal" and "El Azufre" which flows into the sea. Regarding $\mathrm{SO}_{4}{ }^{2-}$ ions, the chemical analysis indicates that $96.15 \%$ of the waters of the upper, meso, and low relief of the Atoyac-Verde river have an average of $0.27 \mathrm{mmol}_{\mathrm{c}} \mathrm{L}^{-1}$ of this ion, a concentration of which according to Can et al. (2014) does not induce high levels of water hardness. Only the samples "Atoyac Zaachila" and "Atoyac Zimatlán river" in the high relief presented a concentration of 1.7 mmol $_{c} \mathrm{~L}^{-1}$, which is attributed to sulfur compounds such as $\mathrm{CaSO}_{4}$ and $\mathrm{MgSO}_{4}$ dissolved by the pluvial precipitation that falls in the river and the contribution of municipal wastewater from riverside towns such as "Oaxaca city" and "San Luis Zimatlán" that should be considered as a source of contamination of natural waters. In general, the concentrations of ion $\mathrm{SO}_{4}{ }^{2-}$ do not exceed the permissible limits established by national and international standards for water of human consumption.

\subsection{Physicochemical Parameters of the Waters}

In general, the waters of the basin presented a $\mathrm{pH}$ range of 6.8 to 8.9 , from slightly acidic to alkaline, which coincides with those found in most natural waters of rivers that cross calcium-magnesium rocks (Hazen, 2015). The maximum $\mathrm{pH}$ values coincide with sites of high concentration of $\mathrm{HCO}_{3}{ }^{-}$and $\mathrm{Na}^{+}$ ions that form the $\mathrm{NaHCO}_{3}$ salt, which is known to produce alkaline hydrolysis in surface waters worldwide. The EC of the waters of the upper, meso, and low relief is on average $328.80 \mu \mathrm{S} \mathrm{cm}^{-1}$, which is considered typical of non-saline waters. Only 5 samples $(9.61 \%$ of the total) were identified with an intermediate EC of $819.6 \mu \mathrm{S} \mathrm{cm} \mathrm{cm}^{-1}$, which according to Ayers and Westcot (1987) is considered slightly saline. Two samples in the high relief ("Atoyac-Zimatlán river" and "Atoyac-Zaachila") and two in the low relief ("San Cristóbal" and "El
Azufre"), comprising $7.69 \%$ of the total samples, presented an average EC of $2320 \mu \mathrm{S} \mathrm{cm}^{-1}$ (the former) and $1199 \mu \mathrm{S} \mathrm{cm}^{-1}$ (the latter). Taken together, the four samples show a statistical significance $(P=0.05)$ for what is moderately saline waters, indicating some risk for human consumption as well as agricultural and livestock activities (NOM-SSA1, 2000; World Health Organization, 2006). The salinization of these waters follows different courses, since, in the first two cases, it is an anthropic salinization due to the discharge of wastewater into natural waters, that is, by chemical contamination, while the third is disturbed by irrigation with high saline well-water and the fourth is affected by the intrusion of sea water from the coast. According to López et al. (2016) and Mercado et al. (2021), the use of these waters can generate infiltration problems in agricultural irrigation. The results indicate that there is an association between the EC and TDS values, confirming that the constant of proportionality $\mathrm{ppm}=0.640 \times \mathrm{EC}($ Richards, 1985) can be used reliably. This explains why the samples that had a low EC presented low TDS values and vice versa. The consistency of the results makes it possible to indicate that $92.31 \%$ of the waters collected upstream do not have saline problems and are suitable for human consumption, and that only the samples indicated last presented an average of $956 \mathrm{mg} \mathrm{L}^{-1}$. Therefore, it is saline water, the use of which for human consumption should be restricted (NOM-127-SSA1, 2000; World Health Organization, 2006). In the present study, a total of 47 water samples from the high, meso, and low relief were found to have an average osmotic potential of $-0.01 \mathrm{MPa}$, which means that these waters do not have salinity problems and therefore are suitable to move in the soil and supply the water needs of forest biomes (Sánchez et al., 2019a, b). Furthermore, five samples, of which three are from the high relief, identified as "Negro river," "Atoyac-Zimatlán river," and "Atoyac Zaachila" and two from the low relief "San Cristóbal" and "El Azufre" presented an intense decrease in $\Psi \pi$ due to the increase in salinity, for which they should have a restriction upon use both for crop irrigation and for human consumption, since they tend to produce physiological drought (Sánchez et al., 2019a, b). Regarding the ES and PS, the results indicate that forty-two samples of the total (19 from the high relief, 13 from the meso relief, and 11 from the low 
relief) representing $82.69 \%$ of the total have ES and $\mathrm{SP}$ index values $<3.0 \mathrm{mmol}_{\mathrm{c}} \mathrm{L}^{-1}$, so it is non-saline water and is considered to be of good quality. Five samples of the upper zone ("Zacañi river," "Mixteco river No. 1," "Negro river," "Ojiate Tlaxiaco river," and "San Andrés Zabache") presented an average ES of $3.0 \mathrm{mmol}_{\mathrm{c}} \mathrm{L}^{-1}$ and PS of $3.69 \mathrm{mmol}_{\mathrm{c}}$ $\mathrm{L}^{-1}$ that identifies them as waters of restricted use (Perez et al., 2019). Only the samples from the sites "Atoyac-Zimatán river" and "Atoyac Zaachila" in the high relief, "San Cristobal" and "El Azufre" in the low relief, presented an average ES index of 7.57 $\mathrm{mmol}_{\mathrm{c}} \mathrm{L}^{-1}$ and PS of $5.81 \mathrm{mmol}_{\mathrm{c}} \mathrm{L}^{-1}$, so its use as irrigation water could generate salinity problems in soils and crops. These waters, according to Pérez et al. (2019) and Camacho et al. (2020), are not suitable for use in agriculture. Regarding SAR, this is a criterion used to evaluate the sodium content of surface waters which when used for irrigation can affect the structure of the soil and its infiltration capacity. A SAR $>2.0$ mmol $_{c} \mathrm{~L}^{-1}$ indicates that $\mathrm{Na}^{+}$predominates over $\mathrm{Ca}^{2+}$ and $\mathrm{Mg}^{2+}$ ions in the soil exchange complex and can produce colloidal dispersion of particles, impermeability, low water infiltration, and crop toxicity (Ayers and Westcot, 1987; López et al., 2016). Based on the above, 47 water samples indicated in Tables 3, 5, and 7 do not present SAR problems and therefore according to Richards, (1985) are classified as C1S1 and C2S1 waters of low and medium sodicity and low salinity without problems of damage to soils, crops, and livestock. In contrast, the water samples "Negro river," "Atoyac Zimatlán river," and "Atoyac Zaachila" in the high relief and "San Cristóbal" and "El Azufre" in the low relief, present SAR values $>2.0 \mathrm{mmol}_{\mathrm{c}} \mathrm{L}^{-1 / 2}$, with statistical difference $(P=0.05)$, that in the same classification are considered of type C3 S1 and C4 $\mathrm{S} 1$, respectively, basically waters of low sodium and high salinity, so they are restricted for agricultural irrigation due to the damage they cause to soils and crops (Fig. 3). These SAR values are associated with urban, industrial, and municipal wastewater discharged into the natural waters of the Atoyac river, on the outskirts of the city of Oaxaca. In the lower part of the basin, they are associated with primary sodification processes due to their proximity to the sea, and secondary ones, due to the use of groundwaters with high concentration saline in irrigation.

Table 7 Others physicochemical parameters of water samples of the Atoyac-Verde River, in the low relief

\begin{tabular}{|c|c|c|c|c|c|c|c|c|}
\hline $\begin{array}{l}\text { Sample number } \\
\text { and identifica- } \\
\text { tion }\end{array}$ & Altitude (masl) & ${ }^{1} \Psi \pi(\mathrm{MPa})$ & ${ }^{2} \mathrm{ES}\left(\mathrm{mmol}_{\mathrm{c}} \mathrm{L}^{-1}\right)$ & $\left.{ }^{3} \mathrm{PS} \mathrm{mmol}_{\mathrm{c}} \mathrm{L}^{-1}\right)$ & $\begin{array}{l}{ }^{4} \mathrm{SAR} \\
\left(\mathrm{mmol}_{\mathrm{c}}\right. \\
\left.\mathrm{L}^{-1}\right)^{1 / 2}\end{array}$ & ESP \% & $\begin{array}{l}{ }^{5} \mathrm{RSC} \\
\left(\mathrm{mmol}_{\mathrm{c}}\right. \\
\left.\mathrm{L}^{-1}\right)\end{array}$ & ${ }^{6} \mathrm{TDS}\left(\mathrm{mg} \mathrm{L}^{-1}\right)$ \\
\hline $\begin{array}{l}\text { 1. Panixtlahuaca- } \\
\text { Leche river }\end{array}$ & 490 & $-0.006 \mathrm{~b}$ & $0.79 \mathrm{~b}$ & $0.59 \mathrm{c}$ & $1.04 \mathrm{~b}$ & 0.27 & $0.10 \mathrm{~b}$ & $72 \mathrm{~b}$ \\
\hline 2. Panixtlahuaca & 439 & $-0.007 \mathrm{~b}$ & $0.84 \mathrm{~b}$ & $0.78 \mathrm{~b}$ & $0.94 \mathrm{~b}$ & 0.12 & $0.00 \mathrm{~b}$ & $88 \mathrm{a}$ \\
\hline 3. Mesones & 413 & $-0.008 b$ & $0.98 \mathrm{~b}$ & $0.72 \mathrm{~b}$ & $1.03 \mathrm{~b}$ & 0.00 & $0.10 \mathrm{~b}$ & $120 \mathrm{~b}$ \\
\hline 4. Zacatepec & 358 & $-0.004 \mathrm{~b}$ & $0.64 \mathrm{~b}$ & $0.46 \mathrm{c}$ & $1.04 \mathrm{~b}$ & 0.27 & $0.10 \mathrm{~b}$ & $64 \mathrm{~b}$ \\
\hline 5. San Cristóbal & 330 & $-0.051 \mathrm{a}$ & $5.62 \mathrm{a}^{*}$ & $4.10 \mathrm{a}^{*}$ & $2.80 \mathrm{a}$ & 2.78 & $0.80 \mathrm{~b}$ & $912 a^{*}$ \\
\hline 6. Мejapa & 282 & $-0.009 \mathrm{~b}$ & $1.03 \mathrm{~b}$ & $0.80 \mathrm{~b}$ & $1.21 \mathrm{~b}$ & 0.52 & $0.10 \mathrm{~b}$ & $120 \mathrm{~b}$ \\
\hline 7. Leche river & 126 & $-0.008 \mathrm{~b}$ & $0.85 \mathrm{~b}$ & $0.74 \mathrm{~b}$ & $0.97 \mathrm{~b}$ & 0.17 & $0.00 \mathrm{~b}$ & $84 \mathrm{~b}$ \\
\hline $\begin{array}{l}\text { 8. Paso de La } \\
\text { Reyna }\end{array}$ & 54 & $-0.015 b$ & $1.59 \mathrm{~b}$ & $1.45 \mathrm{~b}$ & $1.34 \mathrm{~b}$ & 0.71 & $0.00 \mathrm{~b}$ & $196 \mathrm{~b}$ \\
\hline $\begin{array}{l}\text { 9. Verde river } \\
\text { bridge }\end{array}$ & 43 & $-0.015 b$ & $1.95 \mathrm{~b}$ & $1.36 \mathrm{~b}$ & $1.59 \mathrm{~b}$ & 1.07 & $0.19 \mathrm{~b}$ & $168 \mathrm{~b}$ \\
\hline 10. Grande river & 33 & $-0.004 \mathrm{~b}$ & $0.56 \mathrm{c}$ & $0.44 \mathrm{c}$ & $0.87 \mathrm{~b}$ & 0.02 & $0.05 \mathrm{~b}$ & $88 \mathrm{~b}$ \\
\hline $\begin{array}{l}\text { 11. San José } \\
\text { (irrigation } \\
\text { channel) }\end{array}$ & 31 & $-0.015 b$ & $1.72 \mathrm{~b}$ & $1.33 \mathrm{~b}$ & $1.60 \mathrm{~b}$ & 1.08 & $0.18 \mathrm{~b}$ & $180 \mathrm{~b}$ \\
\hline $\begin{array}{l}\text { 12. Pastoría } \\
\text { Dam Irrigation } \\
\text { District } 110\end{array}$ & 27 & $-0.015 b$ & 0.96 & $1.54 \mathrm{~b}$ & $1.26 \mathrm{~b}$ & 0.59 & $0.00 \mathrm{~b}$ & $168 \mathrm{~b}$ \\
\hline 13. El Azufre & 13 & $-0.044 \mathrm{a}$ & $4.91 \mathrm{a}^{*}$ & $3.56 \mathrm{a}$ & $2.73 \mathrm{a}$ & 2.69 & $0.79 \mathrm{a}$ & $484 a^{*}$ \\
\hline
\end{tabular}


Fig. 3 Classification of waters of the Atoyac-Verde river by its salinity and sodicity

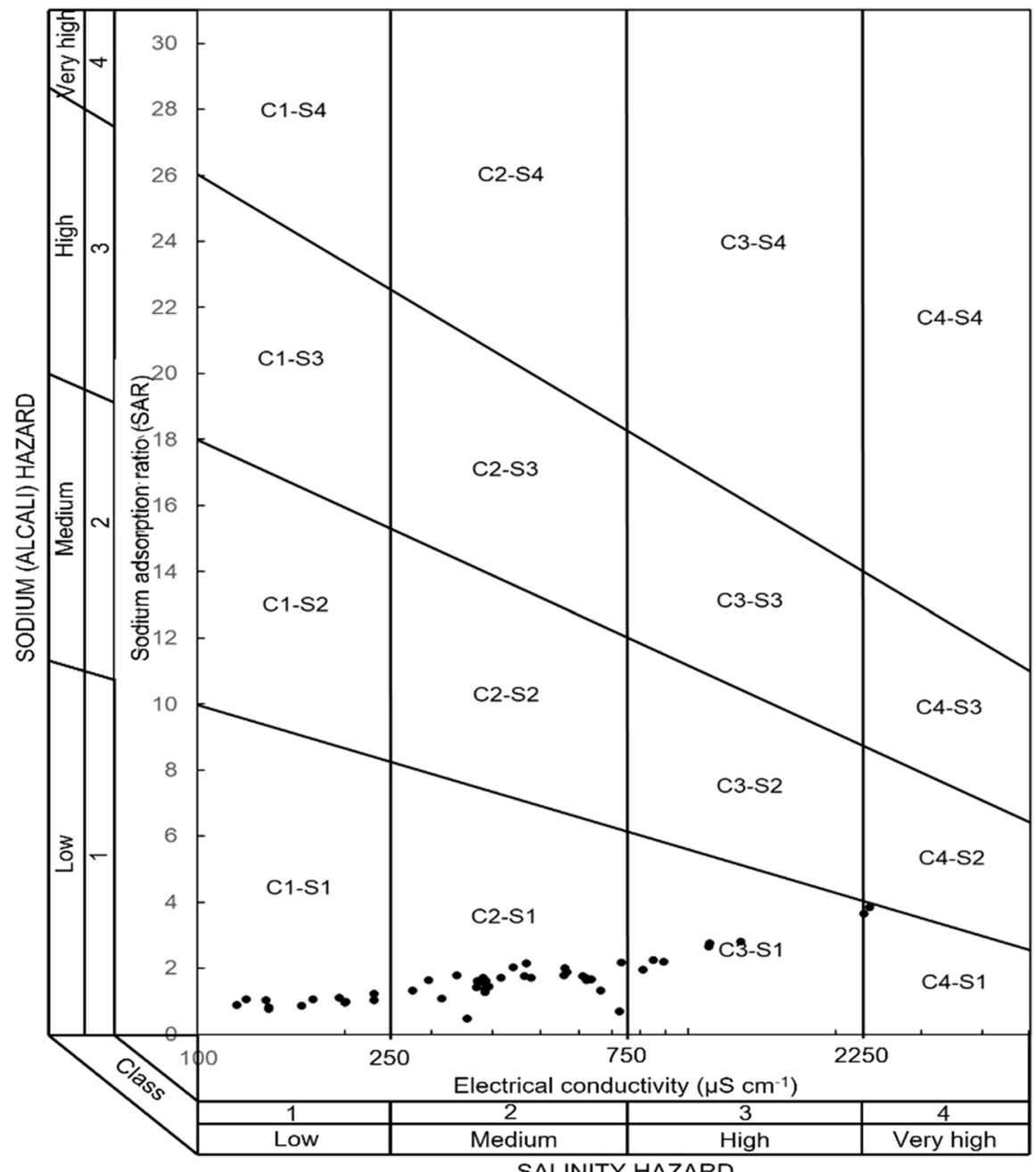

SALINITY HAZARD
ESP, RAS, and RSC are very important criteria of sodicity, since when the waters of a river have a high ESP and RAS, its irrigation can affect their permeability and hydraulic conductivity of soils, while a high RSC can cause the precipitation of $\mathrm{CaCO}_{3}$ and $\mathrm{MgCO}_{3}$, in addition to the obstruction of emitters in drip irrigation systems. This index cited by Cann et al. (2017), indicates that when the $\mathrm{RSC}<1.25$ $\mathrm{mmol}_{\mathrm{c}} \mathrm{L}^{-1}$, there is no RSC problem; when it is from 1.25 to $2.50 \mathrm{mmol}_{\mathrm{c}} \mathrm{L}^{-1}$, the water is acceptable for limited use in irrigation; and when it is $>2.50$ $\operatorname{mmol}_{\mathrm{c}} \mathrm{L}^{-1}$, the waters are not recommended for use in irrigation. In the present study, the 52 samples of Atoyac river basin presented values of $\mathrm{RSC}<1.0$ $\mathrm{mmol}_{\mathrm{c}} \mathrm{L}^{-1}$, therefore according to Mancilla et al. (2020) are considered without RSC problems.

\subsection{Accuracy of Chemical Analysis}

Figure 4 shows the electro-neutrality of the sampled waters. In most laboratories in the world, electroneutrality analyses of up to 5\% are acceptable (Pérez et al., 2019). In the present study, an electro-neutrality value of $0.2 \%$ was obtained, so the results are considered acceptable and valid in keeping with international parameters.

\section{Conclusions}

(1) The waters of the Atoyac-Verde river present a bicarbonate-magnesium-calcium composition, induced by the ionic contribution of the weath- 


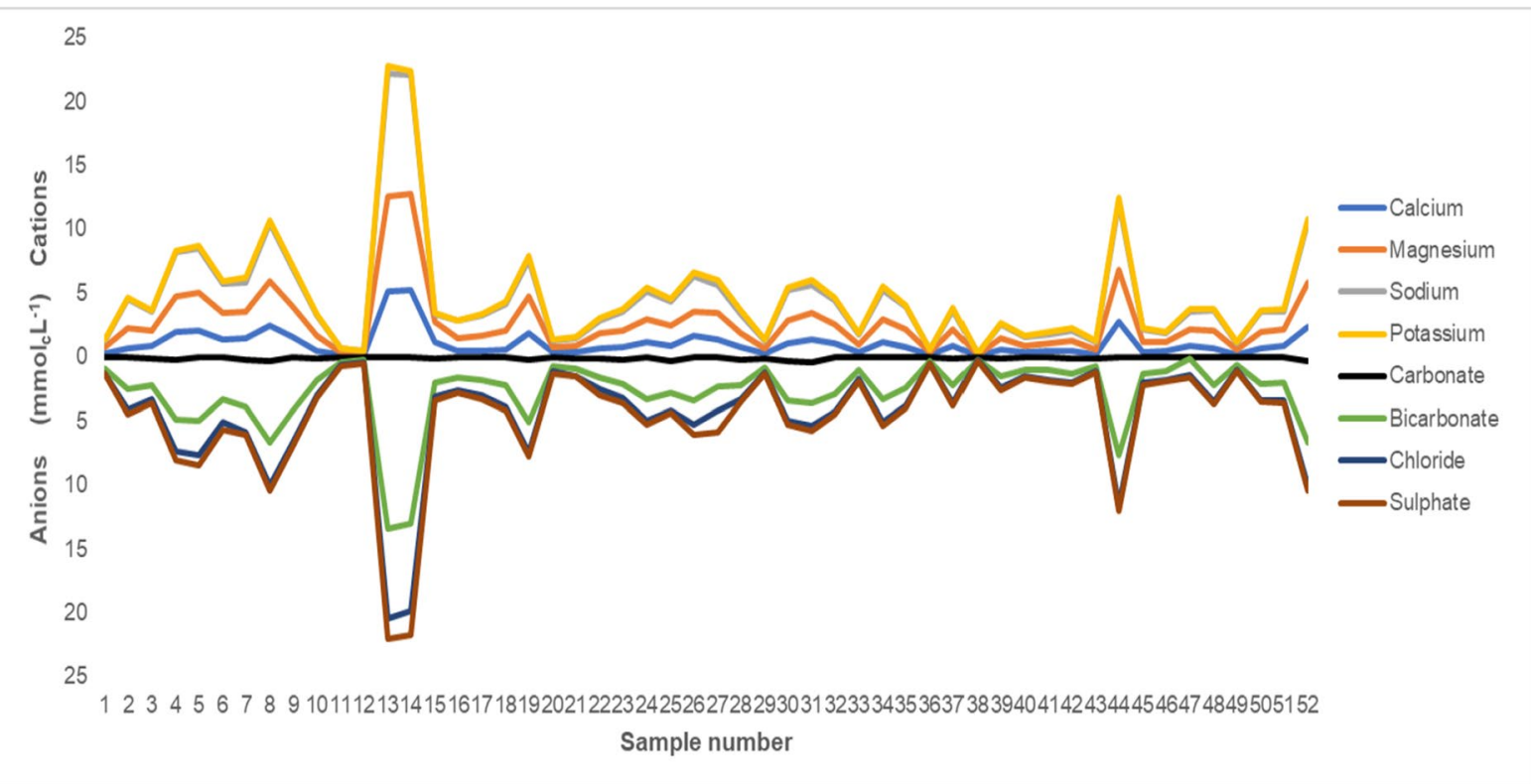

Fig. 4 Electro-neutrality of the water samples

ering of metamorphic rocks of the Oaxaca and Xolapa complexes which it crosses. Its chemical evolution is temporarily altered by the discharge of sewage from technogenic activities into natural channels that flow through the city of Oaxaca. Downstream, they present a homogeneous ionic composition, whose concentration is altered only by rainfall and intensity, without impacting the quality and water sufficiency of the basin. However, sedimentation loads resulting from the erosion of soils denuded by deforestation and the discharge of municipal wastewater from riverside populations alter the chemical composition of the river's waters.

(2) On the coast, the river waters are affected by salinization processes such as marine intrusions and the capillary rise of groundwater due to overuse of semi-deep wells.

(3) Through the basin flow water of type C1 S1 and C2 S1, of low sodium and low salinity. In sum $90.38 \%$ of these have no use restriction. The rest $(9.62 \%)$, is water $\mathrm{C} 3 \mathrm{~S} 1$ and $\mathrm{C} 4 \mathrm{~S} 1$, of low sodium and saline tendency, so is use should be moderately restricted.

Funding The received support provided by the Universidad del Mar and Colegio de Postgraduados for conducting this research.

\section{Declarations}

Conflict of Interest The authors declare no competing interests.

Open Access This article is licensed under a Creative Commons Attribution 4.0 International License, which permits use, sharing, adaptation, distribution and reproduction in any medium or format, as long as you give appropriate credit to the original author(s) and the source, provide a link to the Creative Commons licence, and indicate if changes were made. The images or other third party material in this article are included in the article's Creative Commons licence, unless indicated otherwise in a credit line to the material. If material is not included in the article's Creative Commons licence and your intended use is not permitted by statutory regulation or exceeds the permitted use, you will need to obtain permission directly from the copyright holder. To view a copy of this licence, visit http://creativecommons.org/licenses/by/4.0/. 


\section{References}

American Public Health Association. (1995). Standard methods for the examination of water and wastewater (19th ed.). APHA Inc.

Ayers, R. S. Y, \& Westcot, D. W. (1987). Quality of irrigation water and its use in agricultura. FAO. Irrigation and drainage. 29, Rev 1. FAO, Rome, Italy. 81 p.

Babayan, G., Reshetnyac, O., \& Zakrutkin, V. (2021). A comparative assesment of river water quality in mountain regions of Russia and Armenia. Water Resources, 48, $102-110$.

Barlow, M. P., \& Reichard, E. G. (2010). Saltwater intrusion in coastal regions of North America. Hydrogeology Journal, 18, 247-260.

Camacho, B. A., Ortega Escobar, H. M., Sánchez Bernal, E. I., \& Can Chulim, A. (2020). Physical chemical quality indicators of wastewater in the state of Oaxaca, Mexico. Terra Ltinoamericana, 38, 361-375.

Can, Ch. A., Ortega, E. M., Sánchez, B. E., \& Cruz, C. E. (2014). Quality of wáter for irrigation in the northern highlands of Puebla Mexico. Tecnología y Ciencias Del Agua, 5(5), 77-96.

Can, Ch. A., Cruz, C. E., Ortega, E. M., Sánchez, B. E., Madueño, M. A., Bojorquez, S. J., \& Mancilla, V. R. (2017). Response of Phaseolus vulgaris to the salinity generated by $\mathrm{NaCl}, \mathrm{Na}_{2} \mathrm{SO}_{4}$ y $\mathrm{NaHCO}_{3}$. Revista Mexicana De Ciencias Agrícolas, 8(6), 1287-1300.

Carrera, V. D., Crisanto, P. T., Ortega, E. M., Ramírez, G. J., Espinoza, V. D., Ramírez, A. C., Ruíz, V. V., Velázquez, M. M., \& Sánchez, B. E. (2015). Quantitative and qualitative salinity of the Santa María - Río Verde, hydrographic system, México. Tecnología y Ciencias Del Agua, 6(2), 69-83.

Comisión Nacional Forestal. (2015). National forest and soil inventory: sampling proceduure. Version 15.8. Secretaría del Medio Ambiente y Recursos Naturales, México.

De Scerna, Z.(1965). Geological survey of the southern Sierra Madre, between Chilpancingo and Acapulco, State of Guerrero. Institute of Geology, Bulletin 62-77.

Hazen, R. M. (2015). The history of the earth. Oceano.

Health Secretary. (2000). Official Mexican Water Quality Standard NOM 121-SSA1-2000. Environmental health, water for human use and consumption. Permissible limits of quality and treatment to which the water must be subjected for its purification. Official Journal of the Federation, November 22, 2000.

Kovda, V. A. (1977). Arid land irrigation and soil fertility. Problems of salinity, alkalinity and compaction. In: E. B. Wothington (Ed). Arid land irrigation in developing countries. Environmental problems and Effects. Pergamon Press. 211-236.

Lavrnré, S., Zapater, M., \& Mancini, N. L. (2017). Water scarcity reuse standars in Europe Focus on Agriculture. Water, Air, Soil, and Pollution, 228-251.

López, G. A., Ortega, E. M., Ramírez, A. C., Sánchez, B. E., Can, Ch. A., Gómez, M. J., \& Vázquez, A. R. (2016). Physical-chemical characterization of industrial urban wastewater and its importance in agriculture. Tecnología y Ciencias del Agua, 7(6), 139-158.
Mancilla, V. R., Anzaldo, C. B., Guevara, G. R., Hernández, V. O., Ortega, E. M., Flores, M. H., Can, Ch. A., Olguín, L. L., Mendoza S. I., Sánchez B. E., Cruz, C. E., \& Barreto, G. A. (2020). Heavy metals, arsénic and boron in underground irrigation water in Zacoalco de Torres and Autlán de Navarro, Jalisco. Agrociencia, 54(8). https://doi.org/10. 47163/agrociencia.v5418.2298.

Mercado, T., Ortega, M., \& Feria, D. J. (2021). Study on phreatic wastewater from Temascalcingo Irrigation District, Mexico State, Mexico. International Journal of Engineering Research and Technology, 14(7), 664-673.

Mexican Geological Survey. (2005). Statistical yearbook of mexican mining 2004, Ministry of Economy, Mexico.

Miranda, G. F., \& Hernández E. X. (1963). The types of vegetation of Mexico and their classification. Bulletin of the Botanical Society of Mexico.

National Institute of Statistical, Geography and Informatics. (2010). Geographical synthesis of the state of Oaxaca (166 p.). INEGI Compendium.

Ortega, E. M., Sánchez, B. E., Gómez, G. T., Ortega, B. V., Can, C. A., \& Mancilla, V. R. (2018). Hydroerosion in foothills of the coastal plain of Cozoaltepec Oaxaca México. International Journal of Hydrology, 2(2), 121-130. https://doi.org/10.15406/ijh.2018.02.0006.

Palacios, M. S, \& Gama, J. (1994). Soils, genesis, dynamics and degradation. In: De la Cruz, R. S. (Ed). Earth Sciences Today. Economic Culture Fund, México, 178-202.

Pérez, D. J., Ortega, E. M., Ramírez, A. C., Flores, M. H., Sánchez, B. E., Can, Ch. A., \& Mancilla, V. R. (2019). Nitrate, phosphate, boron and chloride concentration in Lerma river water. Ecosistemas y Recursos Agropecuarios, 6(16), 175-182.

Ray, R. K., \& Mukherjee, R. (2008). Reproducing the Piper trilinear diagram in rectangular coordinates Methods Note. Ground Water, 46(6), 893-896.

Richards, L. A. (1985). Diagnosis and rehabilitation of saline soils and sodics. Salinity Laboratory, USda. Manual 60. Mexico. LIMUSA.

Sánchez, B. E., Ortega, E. M., Sandoval, O. G., Hernández, V. R., \& Estrada, V. C. (2012). Salt lixiviation in coastal alluvial soils of Oaxaca, Mexico, with treated municipal wastewater. Revista Internacional De Contaminación Ambiental, 28(4), 343-360.

Sánchez, B. E., Sandoval, O. G., Camacho, E. M., Valdés, M. F., Rodríguez, L. A., \& Ortega, E. M. (2014). Hydrogeochemical quality of waters of the Copalita river, Oaxaca, México. Revista Internacional De Ciencia y Sociedad, 1(2), 27-41.

Sánchez, B. E., Ortega, E. M., Leal, P. E., Can, Ch. A., Ortega, B. V., Camacho, E. M., \& Mancilla, V. R. (2019a). Interannual salinity in a coastal lagoon of Oaxaca, Mexico: Effects on growth of Black mangrove. Transylvania Review, 27, 9240-9256.

Sánchez, B. E., Ortega Escobar, H. M., Can Chulim, A., Galicia Jiménez, M., Camacho Escobar, M. A. (2019b). Evaluation of osmotic potentials in coastal soils and waters of Oaxaca, Mexico, through prediction equations. Acta Universitaria, 29, 1-22. https://doi.org/10.15174/au.2019. 2125.12

Statistical Analysis System. 2006. Users guide Release 0.13 Statistics. SAS Institute, Care, N.C. USA. 
Szabolcs, I. (1994). Soil and water salinization and desertification. Proceedings of the IV Conference on Desert Development (1993). Postgraduates College, Montecillo, Mexico, 25 to 30 july, 1993. 85-44.

Tolson, G. (2005). The Chacalapa geological fault in southern Oaxaca. Bulletin of the Mexican Geological Society, 57, 111-122.

World Health Organization. (2006). Chemical evolution of water. $3^{\text {a }}$. Edic. Vol. 3. In: Guides for potable water quality. WHO. 1-45.
Zuñiga, E. L., Martínez, H. J., Baca, C. G., Martínez, G. A., Tirado, T. J., Kohashi, S. J., \& Cruz, D. J. (2010). Effect of fertilization with potassium in a vertisol on the quantitie/intensidad ratio (Q/I). Terra Latinoamericana, 28(4), 319-325.

Publisher's Note Springer Nature remains neutral with regard to jurisdictional claims in published maps and institutional affiliations. 